Portland State University

PDXScholar

1983

\title{
The sovereign people, minority rights and state judiciaries : an historical study of Tocqueville's majoritarian thesis
}

Erica Goodwin

Portland State University

Follow this and additional works at: https://pdxscholar.library.pdx.edu/open_access_etds

Part of the Courts Commons, and the Political History Commons Let us know how access to this document benefits you.

Recommended Citation

Goodwin, Erica, "The sovereign people, minority rights and state judiciaries : an historical study of Tocqueville's majoritarian thesis" (1983). Dissertations and Theses. Paper 3250.

https://doi.org/10.15760/etd.3241

This Thesis is brought to you for free and open access. It has been accepted for inclusion in Dissertations and Theses by an authorized administrator of PDXScholar. Please contact us if we can make this document more accessible: pdxscholar@pdx.edu. 
AN ABSTRACT OF THE THESIS OF Erica Goodwin for the Master of Arts in History presented June 3, 1983.

Title: The Sovereign People, Minority Rights and state Judiciaries: An Historical study of Tocqueville's Majoritarian Thesis.

APPROVED BY MEMBERS OF THE THESIS COMMITTEE:

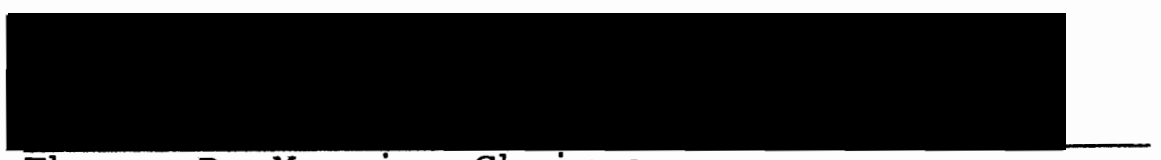

Thomas D. Morris, Chairman

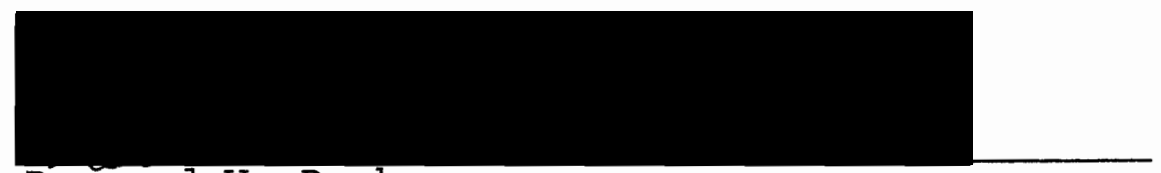

Bernard V. Burke

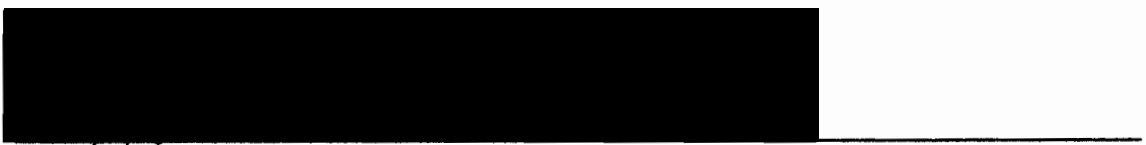

Gord $\phi$ B. Dodds

In the decade of the 1830's, Alexis de Tocqueville published a perceptive analysis of America in the Jacksonian era, which focused upon the customs, manners and intellectual habits of its citizens, and their social condition as seen through its political institutions. He advanced the proposition--a paradox of democracy--that equality of condition was as compatible with tyranny as with freedom. The social consensus, which stemmed from the wide acceptance of doctrine of equality and common wants and interests, when 
brought to bear upon legislator and judge, public official, juryman, and the non-conforming individual, he termed the "tyranny of the majority."

This historical investigation of Tocqueville's majoritarian thesis concentrates upon those points of social tension which are most effectively displayed in one locus of their final resolution, the court system, where, he believed, the judiciary functioned as a powerful bulwark against the excesses of democracy. The judicial opinions of four state supreme courts, which have been selected for their geographical and political balance--Massachusetts, New York, Pennsylvania and Tennessee--are examined for the years 1835-45, that followed immediately upon the publication of his treatise. Specifically, judicial restraint of the aspirations of the assertive, self-confident and politically alert Americans who represented the majority in the legislatures or through the jury system, or claimed, as individuals, certain vested rights, is reviewed.

The results suggest that, in this period of opportunism and dynamic change, the people's prerogative to interpret the law through jury trial received chilly scrutiny; that the concern of the bench was for stable rules to regulate emergent forms of enterprise, and particular interests of individuals, for the good order and harmony of the nation, though their decisions might overturn the political judgment of the majority. By the end of the period, the judiciary had made a decisive stand regarding the nature and locality 
of supreme authority, limiting majoritarian encroachments upon vested rights in politics, economics and property. The courts did not, however, safeguard minority rights that impinged upon majoritarian views which the judges shared. In the despotism of this accord--a paradox of Tocqueville's thesis--lies the tyranny of the majority. 
THE SOVEREIGN PEOPLE, MINORITY RIGHTS AND STATE JUDICIARIES: AN HISTORICAL STUDY OF TOCQUEVILLE'S MAJORITARIAN THESIS

by

ERICA GOODWIN

A thesis submitted in partial fulfillment of the requirements for the degree of

MASTER OF ARTS

in

History

Portland State University

1983 
TO THE OFFICE OF GRADUATE STUDIES AND RESEARCH:

The members of the committee approve the thesis of Erica Goodwin presented June 2, 1983.

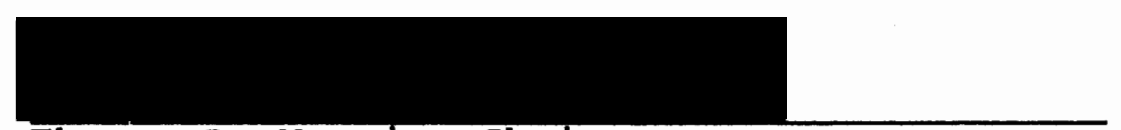

Thomas D. Morris, Chairman

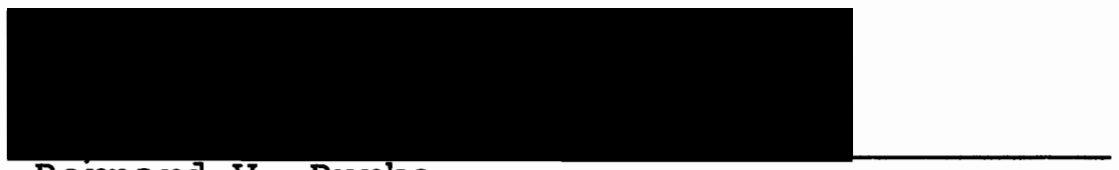

Bernard V. Burke

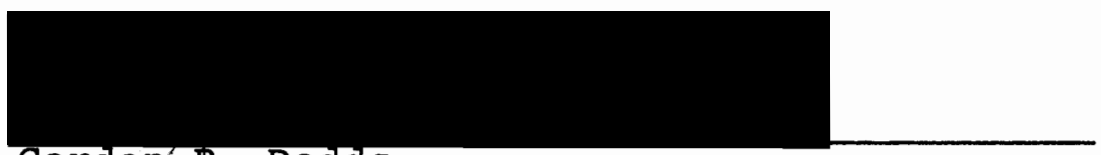

Gordon $\beta$. Dodds

APPROVED :

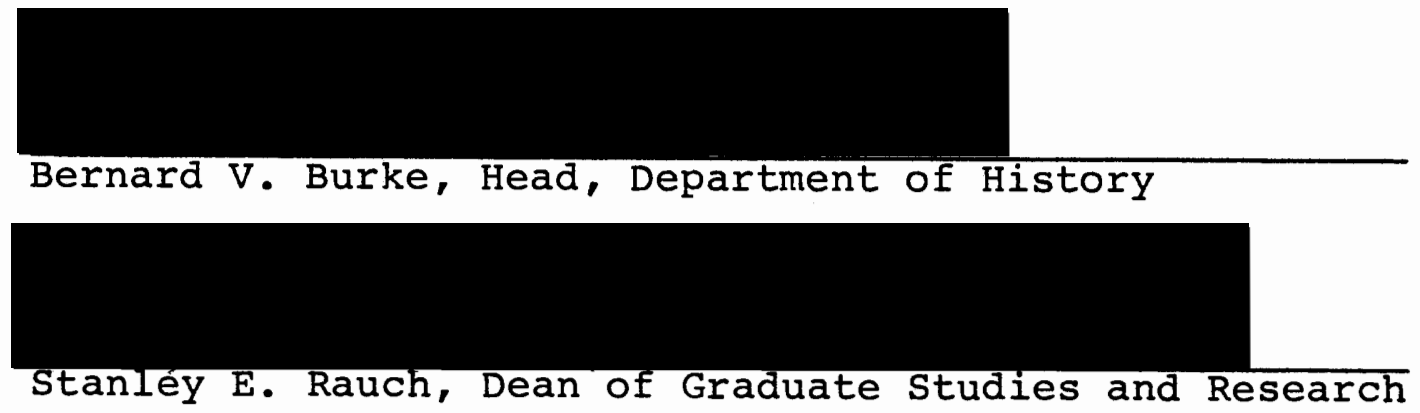




\section{ACKNOWLEDGEMENTS}

It is a pleasure to acknowledge the fine scholarship and expert guidance of Professor Thomas D. Morris, whose keen analysis and constructive criticism helped to focus and strengthen this thesis.

May I thank, too, Professors Bernard V. Burke and Gordon B. Dodds, both historians of singular ability, and Professor Howard Dean, unknown to me, but willing to give of his time and expertise, who served on the thesis committee. 
TABLE OF CONTENTS

PAGE

ACKNOWLEDGEMENTS . . . . . . . . . . . . . . . iii

CHAPTER

I INTRODUCTION . . . . . . . . . . . . 1

II THE JUDICIARY AND THE JURY . . . . . . . 13

III THE JUDICIARY AND THE POLITICAL AUTHORITIES . . . . . . . . . . . 35

IV THE JUDICIARY AND INDIVIDUAL RIGHTS • • • . 65

V CONCLUSION . . . . . . . . . . . . 78

TABLE OF CASES . . . . . . . . . . . . . . . 89

BIBLIOGRAPHY . . . . . . . . . . . . . . 91 


\section{CHAPTER I}

\section{Introduction}

Searching for the universal principles which govern egalitarian societies, so that he might resolve the political conundrum of his time (whether society were more justly ruled by the few or by the many), Alexis de Tocqueville visited America in the early $1830^{\prime} \mathrm{s}$. There he found an image of democracy which kindled his approbation, quickened his apprehension, and inspired a major interpretation of the American experience. In words as cogent as the biblical phrases echoed, he wrote: "The people reign in the American political world as the Deity does in the universe. They are the cause and the aim of all things; everything comes from them, and everything is absorbed in them." ${ }^{1}$ was Tocqueville's assessment an accurate depiction of Jacksonian America, or did it but reflect the prevalent hue of popular sentiment?

To evaluate points of social tension, to discern what each generation thought of the relationship of the individual to the state, and the value placed on liberty--to test the validity of Tocqueville's thesis--judicial opinion

${ }^{1}$ Alexis de Tocqueville, Democracy in America, ed. Phillips Bradley (New York, 1966), I, 58. 
provides rich insights. This discussion focuses on the supreme court records of four states: Massachusetts, New York, Pennsylvania and Tennessee, which provide geographical representation and a measure of political equilibrium. Both the Massachusetts and Tennessee courts had predominantly Whig leanings; in the other two states Democratic jurists were in the majority. The years 1835-45, which witnessed the dynamic advancement of the country in size and material well-being, in technology and business organization, demand particular scrutiny, as both political parties had the opportunity to respond to the age of egalitarianism in the determination of national policy. ${ }^{2}$ Broadly, the evidence suggests that, though the function of politics was to secure to the majority the control and influence to which they were entitled in a democracy, the bench, allegedly an apolitical agency of government, defeated what it perceived to be popular errors, in the interests of political, social, and economic doctrines to which the judiciary adhered. This is not to suggest a complete failure of justice, for the courts provided the vehicle for what Tocqueville would call "the slow and quiet action of society upon itself," ${ }^{3}$ whereby minorities could secure the reconsideration of majority decisions.

In this first decade following the publication of

2 Richard P. McCormick, "New Perspectives on Jacksonian Politics," American Historical Review, 65 (1960), 300.

3 Tocqueville, Democracy in America, I, 416. 
Tocqueville's critique, the sturdy republic, its revolutionary heritage enshrined in its basic institutions, was "far out upon a democratic course." 4 As he had recorded, the nation had advanced steadily towards universal white manhood suffrage, the substitution of a tax qualification or service in the military, for property provisions, giving the impetus to practical democracy. 5 Annual popular elections for the legislature and governor in most states compelled respect for the delegated trust. ${ }^{6}$ Applying fundamental Jacksonian notions to the judiciary, the people, through their representatives, regulated judicial salaries and dictated the duration of appointments; in 1846, New York's constitutional revisions initiated the popular election of judges. Indeed, legislative hegemony was repeatedly demonstrated by the exercise of other "judicial" powers: legislative divorces were granted, marriages validated and dowers awarded, wills rejected by the courts were admitted to probate, mortgages were foreclosed, the administration of estates dictated, 1957), 4 .

4 Marvin Meyers, The Jacksonian Persuasion (Stanford,

5 Tocqueville, Democracy in America, II, 351; Harold M. Hyman and William M. Wiecek, Equal Justice under Law: Constitutional Development $18 \overline{35-1875}$ (New York, 1982), 8. 6 Tocqueville, Democracy in America, I, 83-5, 154. 
and, until 1846, appellate jurisdiction was exercised by the New York senate. 7

The democratization of investment opportunities was secured by regulations for accountability in corporate charters, and the adoption of general incorporation acts after 1830.8 Disestablishment, which promoted religious liberty. was effected in Massachusetts by means of a constitutional amendment. 9 The legislatures responded, too, to reform movements, abolishing imprisonment for debt, modifying severe penalties reminiscent of eighteenth century justice, and improving the prison system, ${ }^{10}$ thus furnishing Tocqueville and his companion with an official reason, and the means, to visit the United States on behalf of the

7 Tocqueville, Democracy in America, I, 255: Bernard Schwartz, The Law in America: a History (New York, 1974), 68; Carl B. Swisher, History of the Supreme court in the United States, The Taney Period (Vol. V) (New York, 1974), 206, 209: After the successful victory over the life judiciary in Pennsylvania in 1839, and the reduction of state judicial salaries in Massachusetts in 1842, efforts were made to eliminate life tenure and lower the salaries of federal judges, including the supreme court, in 1842-3, though this would have required a constitutional amendment. Despite the expansion of responsibility due to the increasing burden of circuit duties as the country grew, the new positions for associate justices notwithstanding, the stipend of Supreme Court justices remained unchanged from 1819 to 1855 . 1945), 337 .

${ }^{8}$ Arthur M. Schlesinger Jr., The Age of Jackson (Boston,

${ }^{9}$ Leonard $w$. Levy, The Law of the commonwealth and Chief Justice Shaw (New York, 1957), 42 .

${ }^{10}$ Hyman and Wiecek, Equal Justice under Law, 47-50. 
French government. 11 observing the prolific exuberance of

legislative activity, Tocqueville wrote:

The authority exercised by the legislatures is supreme. Nothing prevents them from accomplishing their wishes with celerity and with irresistable power, and they are supplied with new representatives every year. 12

The election of Jackson to the presidency in 1828 and 1832, which broke the "chain of decorous successions," 13 confirmed the popularity principle. Tocqueville, whose sympathies were pro-Whig, wrote:

General Jackson, whom the Americans have twice elected to be the head of their government, is a man of violent temper and very moderate talents; nothing in his whole career ever proved him qualified to govern a free people. 14

Yet it was precisely Jackson's scorn of "privilege," or aristocratic pretensions, which drew forth the people's favour. By establishing as a practice the system of rotation in office, Jackson extended democratic participation in government, demonstrating both his faith in the people as the "bone and sinew of the country," 15 and the fear that prolonged office-holding could become linked with economic

${ }^{11}$ James T. Schleifer, The Making of Tocqueville's Democracy in America (Chapel Hill, 1980), 3. Tocqueville's fellow-traveller was Gustave de Beaumont.

12 Tocqueville, Democracy in America, I, 257.

13 Meyers, The Jacksonian Persuasion, 12.

14 Tocqueville, Democracy in America, I, 289.

15 James D. Richardson, A Compilation of Messages and Papers of the Presidents, 1789-1897 (Washington, 1896), III, 305. However, hardly insulated from party politics, the rotation doctrine was generally qualified by political tenet and personal loyalty. 
power. Indeed, any disposition towards exclusiveness by elitist groups repugnant to the democratic man, such as the professions, was rendered ineffective by the redefinition of professional standards, by the legislatures, through the scaling down of educational requirements. This, and the leveling influence of the frontier, gave to Jacksonian society the egalitarian cast which Tocqueville noted as his most "forcible" observation. 16

Consistent with these circumstances was the renewal, under the Democratic party, of the movement for legal reform, a reinvocation of Jefferson's old agrarian vision of a society based upon hard work, honest industry and moderate rewards. Antilegalism in the early nineteenth century was "more pervasive than either of the parties could control, something deep, atavistic, persistent in the community." 17 It represented a belief in man's natural, reasonable and equitable instincts, his "beautiful and unerring sense of justice," and the conviction that law should be relatively simple and comprehensible. 18 It reflected the "strong strand" of middle class antipathy which had developed among merchants of the colonial period, because of legal hostility to their cheaper and speedier extra-judical arbitration

${ }^{16}$ Tocqueville, Democracy in America, $I, 3$.

17 Perry Miller, The Life of the Mind in America: from the Revolution to the Civil War (New York, 1965), 103 .

${ }^{18}$ Miller, The Life of the Mind in America, 102. 
settlements, which had been self-regulated. ${ }^{19}$ It illustrated an antagonism, inherited from the colonial experience, to the use of customary or common law, because of its English origin, and the belief that the law as imported was unnecessarily complex. ${ }^{20}$ The law, it was said, should be "of indigenous growth," 21 "foreign and heathenish words" 22 (Latin) should be dispensed with, so that an ignorant or inattentive lawyer would not misapply one of the various phrases by which suits at law were designated. Distrust of legal technicalities involved not only procedure, but fear of professional cunning and "legal chicanery,"23 which might manifest itself in the manipulation of society by clever lawyers and judges, and concern lest paid advocacy should blight man's moral impulse.

Tocqueville, who was himself a lawyer, wrote: Nothing can be more obscure and strange to the uninitiated than a legislation founded on precedents . .

19 Morton J. Horwitz, The Transformation of American Law, 1780-1860 (Cambridge, 1977), 146.

20 "The Changing Role of the Jury in the Nineteenth Century," Yale Law Journal, 74 (1964), 180, n. 63. See also Thomas A. Bailey, A Diplomatic History of the American People (Princeton, 1970), 200-33: This anti-British enmity was exacerbated by periodic problems concerning the nation's northern borders, and involved the sensitive issue of slavery. Besides affecting Southern sensibilities, the British attempts to crush the African slave trade intensified America's concern over a possible abuse of maritime rights. 21 Mark De Wolfe Howe, ed., Readings in American Legal History (Cambridge, 1949), 472.

22 Charles M. Haar, The Golden Age of American Law (New York, 1965), 230.

${ }^{23}$ Miller, The Life of the Mind in America, 186. 
the American lawyer resembles the heirophants of Egypt, for like them he is the sole interpreter of an occult
science.

For some American practioners of the law, not only

Democrats, though they were the more severe, such censure of the machinery of justice was warranted. They are best represented by Robert Rantoul of Massachusetts. Crusading for the simplification and codification of the laws, he condemned the common law as having its origin in "folly, barbarism and feudality," and charged that judge-made law, based on a "chain of precedents," was judicial legislation, ex post facto law, indefinite and vague. The judiciary "not only usurps the confines of legislation, but runs riot beyond it," he said, "subversive of the fundamental principles of free government." The remedy was to remodel the great body of the law, merge the procedures of law and equity, and enact the result in the form of statutes, for "statutes speak the public voice." 25 Other lawyers sought to give to the reform of law a systemic basis and legislative sanction. In 1825, Edward Livingston completed four codes for the state of Louisiana, ${ }^{26}$ which, when codification

24 Tocqueville, Democracy in America, I, 277. Miller, in The Life of the Mind in America, 186, uses this quotation in the context of legal morality. As Tocqueville fraternised with whig intellectuals, many of whom were lawyers, it seems that he intended rather to infer that American jurisprudence as a system was chaotic, compared with the French, an achievement of the Napoleonic Codes.

$$
\begin{aligned}
& 25 \text { Howe, Readings in American Legal History, 474-8. } \\
& 26 \text { Haar, The Golden Age of American Law, 268-9; Swisher, }
\end{aligned}
$$
The Taney Period, 34 . 
activity spread, were circulated throughout the country, finding greater acceptance in the new states of the west, though statutory revisions were enacted in Massachusetts and Pennsylvania in the $1830^{\prime}$ s. $^{27}$ In New York, the first code of David Dudley Field, the state's leading codification advocate, was approved in 1848.28

Pondering upon the overwhelming authority of the majority in America, 29 Tocqueville decided that its basis lay in annual elections, in the right of electors in certain states to require that their representatives submit to mandates, in the legislative domination over the executive branch, and in the reach of the people into the sphere of judicial independence through salary and tenure adjustments. 30 The moral authority of the majority lay in their collective intelligence and wisdom, was enlarged by the wide acceptance of the doctrine of equality, 31 and a sense of community, or harmony of interests, which their history and traditions nourished. Several important results followed. Instability of the laws,

${ }^{27}$ Charles Warren, A History of the American Bar (New York, 1939), 528 .

${ }^{28}$ Swisher, The Taney Period, 344.

29 Tocqueville, Democracy in America, I, 57: "The principle of the sovereignty of the people has acquired in the United States all the practical development that the imagination can conceive. . . The people reign without impediment."

${ }^{30}$ Ibid., I, 254-5, 154.

${ }^{31}$ Ibid., I, 393: Not only its ideological foundation, but basic education ( $I, 316)$ and material prosperity ( $I$, 292-3) enhanced this sentiment of equality. 
and variations in their administration, mirrored the fluctuating membership of the dominant branch of the government. 32 The politically viable figure, or the popular writer, was he who conformed, and reinforced society in its assumptions of superiority. 33

"Unlimited power is in itself a bad and dangerous thing," wrote Tocqueville. Seeing the "irresistible strength" of the democratic institutions in America, he believed that he detected a "germ of tyranny," for to whom could an individual or a minority apply for guarantees against the abuse by the many of its authority?

If to public opinion, public opinion constitutes the majority; if to the legislature, it represents the majority and implicitly obeys it; if to the executive power, it is appointed by the majority and serves as a passive tool in its hands. The public force consists of the majority under arms, the jury is the majority invested with the right of hearing judicial cases, and in certain states even the judges are elected by the majority. 34

However, wrote Tocqueville, the potentially despotic pressure of public opinion was diminished by the absence of a centralized administration (because of federalism), by the

32 Ibid.. I, 258, 262, 206: In discussing the frequency of elections and the "perpetual mutability" of the law, Tocqueville at first suggested that an instinctive taste for variety, a "characteristic passion," had guided popular rule. Later, he exposed democracy's negative concept of government: "The people in America obey the law not only because it is their own work, but because it may be changed if it is harmful; a law is observed because, first, it is a self-imposed evil, and, secondly, it is an evil of short duration."

${ }^{33}$ Ibid., I, 265-6.

${ }^{34}$ Tocqueville, Democracy in America, I, 261, 416. 
division of the states' authority into counties and municipalities, and by the very vastness of the nation, so that natural sanctuaries of liberty could exist in "concealed breakwaters." 35 Further, the tyranny of the majority was mitigated by the predominance of the legal profession. The prominence of this ubiquitious group was assured by education, and by opportunities in both private law and public service, where social adjustments were made in legal terms, to infiltrate the whole community. Cautious, orderly, and conservative by training, they checked the passions and impetuosity inherent in popular government, assuming for themselves the role of preserving the fabric of society. ${ }^{36}$ Finally, though he had praised the jury as an "eminently republican element in the government, " 37 he proffered it as a co-agency, with the legal profession, in "moderating the movements of the people," for, by sanctioning the decision of the court in civil cases, jurors promoted the judge's responsible role, and transmitted into the community the principles whereby the law promoted the ends of justice. 38

Did the judiciary function as a limit upon majoritarian tyranny? Points of tension between the people's competence as jurors, to interpret the law, as legislators, to resolve social problems, and as individuals, to regulate their interests responsibly, and the judicial conception of

$$
\begin{array}{ll}
35 \text { Ibid., I, 87-89, 271-2, 290. } & { }^{36} \text { Ibid., I, 270-80. } \\
37 \text { Ibid., I, 282. } & { }^{38} \text { Ibid., I, 385-6. }
\end{array}
$$


harmonious social progress, are effectively displayed in the Supreme Court records of Massachusetts, New York, Pennsylvania and Tennessee. Highly representative cases, though not every conceivable case, in the decade following the publication of Democracy in America, are discussed in the ensuing pages, to test Tocqueville's thesis that majoritarian tyranny was implicit in the American conception of democracy . 


\section{CHAPTER II}

\section{The Judiciary and the Jury}

Tocqueville regarded the institution of the jury as an eminently republican institution, "as direct and as extreme a consequence of the sovereignty of the people as universal suffrage." As potent as the suffrage privilege, because it applied and sanctioned the laws by punishing transgressors, it was "that portion of the nation to which the execution of the laws was entrusted," and was imbued with the "notion of right." Viewing Americans as strikingly litigious, he applauded the system as a "gratuitious public school, ever open" which prepared the people for exercising the rights and responsibilities of citizenship, and cultivated an acquaintance with the law. An essential element in criminal trials, it balanced the power of the judiciary and its potential to oppress with the competence of the people. 1

Yet, he also saw the jury as a major check on majoritarian despotism. In civil cases, he argued, the judge, because of his commanding role, exercised an intellectual domination over the jury, who, in turn, while augmenting the

${ }^{1}$ Tocqueville, Democracy in America, I, 280-3. 
practical knowledge of the community, enhanced his moral authority by sanctioning his decision. 2

The tension revealed in this dramatic shift in the relationship of judge and jury in Tocqueville's assessment of criminal and civil trials is augmented by his perception of a "germ of tyranny" in the jury, which, as an agency of government, could perpetrate specific acts of oppression against minorities and dissenting individuals. ${ }^{3}$

What, then, was the status of trial by jury in 1835? By custom, the American colonists had settled the problems of pioneer populations on both civil and criminal matters through simple arbitration procedures, or lay referees performed limited regulatory roles while juries, judging transgressions by absolute moral standards, decided questions of both law and fact. ${ }^{4}$ The public cherished the basic assumption that legal experts were unnecessary; that Every man might safely act as his own lawyer while society stood ready to protect his legal rights. The glowing promises of social justice, once British power was overthrown, were protected in the republican creed. Therefore, where the republic remained primarily an undeveloped agricultural area, the traditional conception that the jury had the right to decide questions of law was recognized and accepted, but generally only in criminal cases. For, as redress to the civil law

$$
\text { 2 Ibid., I, 284-7. 3 Ibid., I, } 260 .
$$

4 Howe, "Juries as Judges of Criminal Law," 591. 
was beyond the reach of most people because of cost and delay, and cases were seldom notorious, judges had been able, unobtrusively, to narrow the province of the jury in civil actions, and, in some areas, to eliminate it.

This was demonstrated in commercial litigation, particularly in the port cities of Philadelphia, Boston and New York. 5 The use of extra-judicial means of settlement through arbitration, during the colonial period, had enabled merchants to avoid lengthy and extensive lawsuits before a professional bar not yet attuned to commercial interests. 6 However, because of the growing number of appeals from arbitration to the state courts, judges, by finding technical deficiencies, were able to subvert this system, and, by 1800 marine insurance cases had become the mainstay of commercial lawyers. ${ }^{7}$ The expedient identification of commercial law with natural law principles, or the "general law of nations," marked the beginning of a possible alliance between the mercantile classes and the legal profession, 8 and the question of the control of juries took on a new significance. To resolve the dichotomy between the jury's equitable inquiry and certainty, an essential element of economic planning, judges employed two procedural devices: the "special case,"

5 Horwitz, The Transformation of American Law, 141. 6 Ibid., 145-6. Arbitration committees were generally established by Chambers of Commerce.

7 Ibid., 141. One of Hamilton's first cases terminated in a damage judgment of $\$ 120,000$.

${ }^{8}$ Ibid., 144 
which reserved points of law for the bench, and the reversal of jury verdicts "contrary to the weight of evidence." 9

As Alexander Hamilton had admitted in 1787 , a gradual but significant erosion of the jury's role in civil cases had occurred. There was a "material diversity" in the extent of the institution in the state courts in these actions (in New York, courts of admiralty, probate and chancery proceeded without the aid of a jury); he expressed "doubts as to [its] essentiality . . to liberty" in civil cases, where questions were, he believed, "too complicated" for its effective use. However, he assured the people of New York that, though the Constitutional Convention had failed to protect jury trial in civil cases, it was seen as a "valuable safeguard to liberty . . . and a very palladium of free government." 10

During the first few decades of the nineteenth century, the courts of New York generally left questions of law to the decisions of juries in all criminal cases. ${ }^{11}$ Between 1835 and 1845, in the only case which pertained to the

${ }^{9}$ Horwitz, The Transformation of American Law, 142. The first in Pennsylvania occurred in 1788, and in New York in 1799, both to overturn jury verdicts against marine insurers.

10 The Federalist No. 83, ed. Clinton Rossiter, (New York, 1961), 499, 506, 509. Hamilton pointed to legislative authorization of the jury's decline in these fields.

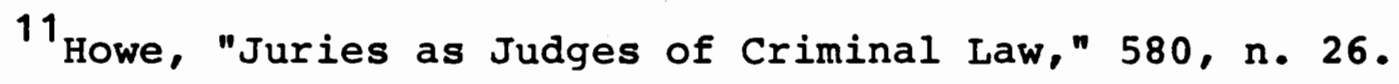


jury's right to determine the law and the fact, ${ }^{12}$ the

supreme court predicted that a procedural change would demand a sharp distinction between law and fact, and a corresponding separation of function between judge and jury. People V. Rathbun (1839) concerned an indictment for forgery. In the trial court, the judge, before submitting the case to the jury for their decision on both the law and the fact, had reviewed the evidence, some of it circumstantial. The defendant's counsel objected to his summation, perceiving a distortion which did not favour his client, and presented a lengthy list of errors. Justice Esek Cowen, for the Democratic court, ${ }^{13}$ explained the principle by which a remedy by bill of exceptions, a recent refinement by statute, could be introduced. Criminal law allowed review by bill of exceptions of legal questions, he said, and conclusions from fact by the judge were to be taken as merely advisory to the jury, who were the "tribunal to correct the errors, in point

12F. N. Thorpe, ed., The Federal and State Constitutions, Colonial Charters and other Organic Laws of the States, Territories and Colonies now and heretofore forming in the United States of America (Washington, 1909), 1648 .

${ }^{13}$ In this period the court consisted of John Savage, Chief Justice - Democrat (Cyclopaedia of American Biography, Appleton and Company, 1888, V, 409); Samuel Nelson, Chief Justice - Democrat (Dictionary of American Biography, VII, 422); Green C. Bronson, Chief Justice (1845) - Democrat (Appleton's, I, 384); Freeborn G. Jewett and Esek Cowen, both of whom remain elusive, though the latter's brother was a leader of the Whigs in upper New York in the 1840's and was also a lawyer (National Cyclopaedia of American Biography, XII, 58). The Chancellor was Reuben $\mathrm{H}$. Walworth - Democrat (Dictionary of American Biography, $\mathrm{X}, 406$ ). 
of fact, both of the judge and counsel." 14 Deeming the errors to be factual, "frivolous . . or irrelevant," 15 he added that, though it appeared to the defendant's counsel that the trial judge's charge to the jury was more than an advisory declaration on the facts, the judge had concluded by resigning the case to the jury upon every point of law and fact. This was "more favorable for the prisoner than some books required." 16 citing U.S. V. Battiste. ${ }^{17}$ where it was held that the instructions of the court upon the matter of law were conclusive upon the jury, he declared that this decision now had "additional force under a system of criminal law which allows a review by a bill of exceptions of the legal questions." 18

Pennsylvania's constitutional provision gave the jury the right to determine the law and the fact under the direction of the court, in indictments for libel and other cases. $^{19}$ The meaning of libel in the jury clause is associated with the highly partisan dispute over the passage of the federal Sedition Act of 1798, which supposed that the government could be criminally assaulted by the expression of critical views. Pushed through by the extreme wing of the Federal party, this statute, they claimed, liberalized the traditional law of seditious libel by permitting truth

\author{
1421 Wendell, 548. ${ }^{15}$ Ibid., 547. \\ ${ }^{16}$ Ibid., 526. 172 sumner, 240 (1835). \\ 1821 Wendell, 526-7. \\ 19 Thorpe, ed., Federal and State Constitutions, 3122.
}


as a defense, and by allowing the jury to decide whether an utterance were libelous. For the traditional or common law, which had been incorporated in the First Amendment, merely prohibited censorship prior to publication, permitting subsequent discipline for licentious or seditious abuse, truth providing no protection, and the judge having sole power to determine the crucial question of whether the defendant's remarks were libelous, or of a bad tendency. The beleaguered Republicans, attacking the act as unconstitutional, asserted that the First Amendment had outlawed seditious libel. Therefore, the jury had the power to determine the ultimate legal question of the substantive meaning of a statute, but was bound to follow the court's opinion in matters concerning evidence and constitutionality. ${ }^{20}$ This seems to have been the accepted practice in Pennsylvania from its early years. 21

Judicial dicta during the first half of the nineteenth century suggest, however, that judges were bringing a new policy orientation towards the jury's role. Kolb's Case (1835) had reference to an act of 1815, which provided for the holding of a special court in divorce cases. Counsel had implied that the act required courts only where a jury was necessary to determine a suit. Justice John Kennedy, 20 Howe, "Juries as Judges of Criminal Law," 587. 21 Ibid., 595. 
for the Democratic court, 22 ruled that:

As the province of the jury is only to decide on the facts and not the law of the case, it is obvious that in every case where the parties agree as to the facts of it, a jury is unnecessary, and that the action must be tried and decided by the court alone. 23

Again, in Sypher v. Long (1835), an action for debt on a note under seal, Chief Justice John Gibson, asserting that it was an error to charge a jury to find a fact without evidence, added: "In what is called, in other respects, a 'hard case,' juries are often sufficiently prompt to break through the law, without the suggestion of a pretext for it." 24

In Brown v. Brown (1837), the trial court had submitted as a matter of fact to the jury the division of property by a will. Justice Kennedy objected to the ruling by the jury, hinting that justice characteristic of jury determinations was rough, informal, and arbitrary. Where the jury had established a crooked line, he said, a straight line was obviously indicated, and would prevent subsequent strife and litigation. He believed it to be the duty of the court to interpret instruments of writing where precision and certainty were required. He feared that a jury would be

22 Pennsylvania's court consisted of John B. Gibson, Chief Justice (Dictionary of National Biography, IV, 254); Molton C. Rogers and Charles Huston, who, like Gibson, were appointed by Governor Shulze, Democrat, in the 1820's (National Cyclopaedia of American Biography, XIV, 39, 145); John Kennedy, who was appointed by Shulze in 1830 (Who was Who in America, 1607-1898, 48), and Thomas Sergeant, Democrat (Dictionary of American Biography, VIII, ii, 590).

23 Watts, 156. 24 Ibid., 254. 
tempted to make "the most accommodating partition of the land between the parties . . according to their notions of what might have been the intention of the testator," or might "equalize the bounty . . believing that it would have been just as equitable in him to have done so." 25

In 1837, the court intimated that the law was becoming so complex that interpretations, even of facts, were becoming a matter for professionals. In Yoter v. Sanno, Chief Justice Gibson found that though it was usually the business of the jury to deal with presumptions of mere fact, because they were now of growing importance in the evaluation of evidence, they were "conclusions from experience," 26 upon which the court ought to adjudicate. He reversed the jury's finding that a "lost" paid prize ticket for a lottery, now lapsed, was not sufficiently accounted for; payment must be assumed.

The provisions in the 1834 Constitution of Tennessee concerning the jury gave them "in all indictments for libels - a right to determine the law and the facts, under the direction of the court, as in other criminal cases." 27 This was a verbatim repetition of the clause in Pennsylvania's Declaration of Rights, with the addition of the word "criminal," and the insertion suggested that its source could lie $25_{6}$ Watts, 55. $\quad{ }^{26} 6$ Watts, 165. 27 Thorpe, ed., Federal and State Constitutions, 3428. 
in Fox's Iibel Act. ${ }^{28}$ If this Libel Act were applicable in the Tennessee constitutional provision, the words "under the directon of the court" referred to the court's instructions upon the legal question of the defendant's guilt or innocence. The following cases concerning the jury's role in Tennessee reflect the confusions concerning the source of the provision, and ambiguities inherent in its interpretation. 29

McGowan V. State (1836) was a case against gaming. The defendant's counsel charged that, among other errors, the trial judge had erred in claiming that the court was the judge of the law, and that the jury must receive the law as expounded by the court. He believed it to be an accepted practice in the state that the jury, "sworn to make a true deliverance between the state and the accused," had the power to render a general verdict of not guilty, and, as no tribunal could contest the decision, the legal power admitted the legal right. 30 wise juries would exercise this

${ }^{28}$ Howe, "Juries as Judges of Criminal Law," 585. Under the common law, the jury had passed only upon the fact of publication, while the judge decided the question of whether the defendant's remarks were libelous. Fox's Libel Act was a reforming English statute of 1792 which gave to the jury the right to pronounce the verdict "under the directions of the court." It had, however, received two conflicting interpretations: that, in prosecutions for libel, as in all criminal cases, the jury might find a verdict upon the whole matter of the defendant's guilt or innocence, or, that it was the jury's duty to follow the instructions of the court upon all questions of law.

$$
\begin{aligned}
& 29 \text { Ibid., 588, 598-600. } \\
& 30_{9 \text { Yerger, } 191 .}
\end{aligned}
$$


power circumspectly, and, to counter the oppression of corrupt judges, must find against a court which they believed to be wrong. Such power was given by the Constitution. If the jury did not have the right to judge the law, counsel could not argue the law before them, and the accused would be denied the right of full defense.

Justice William Reese ${ }^{31}$ sustained the trial court's instruction that the "court was to be the judge of the law, and the jury exclusively the judges of matters of fact, and it was the duty of the jury to receive the law as laid down and expounded by the court," but he described these words as "perhaps inaccurate, and may be, too strong." 32 The jury were not the exclusive judges of the facts, he said, for the court could set aside a guilty verdict if, on appraisal, it appeared that the conclusion belied the weight of evidence. Quoting Justice Samuel Putnam, in Commonwealth v. Knapp, 33 however, he gave the jury discretionary power to be guided by the court in matters of law, but, "when the jury undertake to decide the law, in opposition to the advice of the court, they assume a high responsibility, and should be very

${ }^{31}$ In early 1835, the state's Superior court consisted of John Catron, Chief Justice, Jacob Peck and Nathan Green, all chosen by the Jacksonian legislature in the $1820^{\prime} \mathrm{s}$ (Swisher, The Taney Period, 60). In December, 1835, the Supreme Court was established by statute, and Green was joined by William B. Turley and William B. Reese, all appointed by Governor Cannon, who was a Whig (Stanley F. Flomsbee, Robert E. Corlew, Enoch L. Mitchell, Tennessee, a Short History (Knoxville, 1969), 192.

32 9 Yerger, 194-5.

3310 Pickering, 495 (1830). 
careful to see clearly that they are right." 34 with this admonition, he affirmed the decree.

The following year, Justice Nathan Green, in Dale v. State, sustaining a judgment of murder against Dale in the circuit court, re-affirmed, after "mature consideration," the opinion of the court in McGowan, which he regarded as "substantially correct."35 He denied the bill of exceptions artfully presented by the defendant's counsel, who had drawn from the trial judge a view, while the jury was in seclusion, which differed from the statement of the court in McGowan. The court was obviously disapproving, but not yet prepared to deny the jury's right conclusively. By 1842, however, the court, through Justice Reese, claimed that it was "too obviously correct to be drawn into question or argument," 36 that the jury were not the judges of the law, and that the insistence of the defendant's counsel that the jury were at liberty to disregard the law as given to them by the court was a proposition "of dangerous tendency - . and not permitted by the laws of the state." 37 The court had come to the conclusion, it seems, that only clear instructions to juries, necessary to prevent "novel" interpretations of the law, would "secure the repose of society." 38

The right of the jury to determine the law in the colony of Massachusetts had been recognized in criminal cases,
349 Yerger, $195(1836)$.
3510 Yerger, 555.
$36_{3}$ Humphreys 37
277, McCorry V. King's Heirs.
Ibid., 270 .
${ }^{38}$ Ibid.. 276. 
though it remained inconclusive in civil cases. ${ }^{39}$ In 1808 , however, the legislature affirmed the jury's common law right to decide, at their discretion, both the law and the fact, by a general verdict. 40 This statute, which was never interpreted by the courts, seens clearly to have been reflected in Commonwealth v. Knapp ${ }^{41}$ and Commonwealth v. Kneeland. In the latter case, Chief Justice Lemuel Shaw, for the predominantly whig court, 42 stated that, in criminal cases, "by the form in which the issue is made up, the jury pass upon the whole matter of law and fact." 43

In 1839 , the court appears to have moved towards a more authoritative role. In that year, Democratic Justice Marcus Morton rejected the plea of defendant's counsel that the issue of probable cause was a mixed question, involving both law and fact, which ought to be submitted to the jury. In stone v. Crocker, he stated that, to have taken the opinion of the jury as to whether certain facts and circumstances amounted to probable cause, would have been to obtain their judgment on a pure question of law. This would have confounded the functions of judge and jury, which should be kept as distinct as possible. 44

39 The Changing Role of the Jury," 174, n. 27.
40 Ibid., 174. 4110 Pickering 495 (1830).
42 The Massachusetts court during this period consisted of Lemuel Shaw, Chief Justice, Samuel Putnum, Samuel Wilde, Charles Dewy, Samuel Hubbard, and Richard Fletcher, all Whigs, and Marcus Morton, Democrat (Levy, The Law of the Commonwealth and Chief Justice Shaw, 337-8).

${ }^{43} 20$ Pickering 222 (1838). $\quad{ }^{44} 24$ Pickering 84 . 
In 1845, in an action involving the liquor license laws, Justice Charles Dewey upheld the trial judge's finding that it was the province of the court to rule upon the meaning of statutes, and the duty of the jury to follow the ruling of the court on a question of law, which, in the case at hand, involved a judgment as to whether the addition of water and sugar added to gin made it less "spiritous." The jury, however, had the power to return such verdict as they saw fit, even against the instructions of the court. 45

This decision was further amplified in Commonwealth v. Porter (1845) where the defendant was charged with having violated a statute forbidding innkeepers from selling intoxicating liquors. The trial judge had instructed the jury that, though they possessed the power of rendering a general verdict in opposition to the court's ruling, and would be free of attaint, 46 they would be over-ruled and reversed. Porter's counsel contended that power and right were "convertible terms;"47 that if the law gave the jury power to determine the law and the fact in a general verdict, it gave them the right also. By withholding power from the court to alter a verdict of not guilty in criminal cases, the law assumed the jury's right to exercise this power independently of the judge; if a jury convicted against the opinion

4510 Metcalf 14 , Commonwealth v. White.

${ }^{46}$ The conviction of a jury for giving a false verdict, now an obsolete procedure.

4710 Metcalf, 169. 
of the court, the remedy lay with the court to set the verdict aside. Surely, he said, the jury resolved both law and fact when they deliberated on a general verdict, for why distinguish it from a special verdict if they did not? Indeed, if a jury could not determine the law according to their judgment and conviction, their verdict was forced upon them, their oaths were meaningless, and the citizen was deprived of his right to be judged by his peers. To suggest that the jury would not comprehend the law was to "disparage their office as well as to impugn the law, which does not assume incapacity where it imposes duties to be performed." 48 He saw the jury as a safer deposit of popular rights in a free government than a court, which was not responsible for its judgments, though they be wrong or corrupt. Until the excitement caused by the liquor license cases, both the common law and precedent had sustained the right of juries to decide the law, and such had been the instruction in Commonwealth v. Knapp and Commonwealth v. Kneeland. Nor had the practice of counsel to argue the law to the jury for their deliberation ever before been denied or questioned in the judicial history of the state.

Justice Shaw, setting aside the verdict, left with counsel the right to address the jury on questions of law, citing the "latitude which has been allowed in this Commonwealth, by a long course of practice." 49 He accepted that observations by counsel must contain an exposition of

$$
4810 \text { Metcalf } 274 . \quad{ }^{49} \text { Ibid.. } 285 .
$$


the law, to the possible edification of all, but he saw as "separate and distinct," 50 the question of whether the jury might then decide authoritatively upon the law. Vigorously denying this right, 51 he stated that, since the adoption of jury trial as a settled mode of proceeding in courts of justice, it had been recognized that it was the province and duty of judges to decide the law, and of juries to consider and weigh facts. Upon this was founded the whole doctrine of bills of exception, which gave to all persons the full benefit of revision by the court of last resort on all questions of law. According to the Constitution of the Commonwealth, every citizen was entitled to the authoritative declaration and application of the laws, fixed and permanent, impartial and equal in operation. Hinting that a jury, having a rightful authority to decide questions of law, might legitimize local prejudices, he asked how the security of citizens could be protected without a steady and uniform interpretation of the laws. And it was the "more necessary to adhere to this rule," he said, because it was "within the province - . of the judicial department, on proper occasions, to decide whether an act.. . is within the just limits of legislative power, and whether it is constitutional and valid." 52

\section{Metcalf 275 .}

${ }^{51}$ In 1855 , Dewey would suggest that these two rulings were "not in entire harmony." (Commonwealth v. Anthes 5 Gray 238.) 
Commonwealth v. Abbott, in 1847, decided the question of whether the jury was bound to follow the court's opinion on constitutionality. Shaw sustained the trial court's ruling that a juror could not be disqualified because he had formed and expressed an opinion on the constitutional validity of the liquor license laws, but he denied the juror's right to determine constitutionality, insisting that it was his duty to be governed by the instructions of the court, even though his opinion might differ. In this way he frustrated counsel's design to obtain an acquittal on a statute nullified by a jury. 53

The political response stimulated by these cases resulted in an amendment in the state constitutional convention of 1853, giving juries the right to interpret the law. When this amendment, together with the new constitution, was rejected by the voters, the legislature passed a statute in 1855 which provided that "in all trials for criminal offences, it shall be the duty of the jury . . to decide at their discretion. . both the fact and law involved in the issue. " 54

Shaw reinterpreted this statute in Commonwealth v. Anthes (1855). Asserting that it was a "declaratory act, making no substantial change in the law regulating the

\section{Metcalf 120 .}

${ }^{54}$ Commonwealth v. Anthes, 5 Gray 185. 
relative rights and functions of the court and the jury," 55 he held that the trial judge had erred in permitting the jury to determine the meaning of the liquor license law. Several cases in the state bearing upon this statute justified a fresh analysis of procedure in criminal prosecutions, and Shaw proceeded to give a lengthy and definitive opinion on the respective provinces of judge and jury.

The Constitution and the common law entrust to the judge, he said, the determination of the law on which an indictment is founded. This required proficiency and skill in jurisprudence, and an accurate and complete knowledge of constitutional law. Adjudication of facts, which demanded a practical knowledge of affairs, discernment of motives, integrity and impartiality, was invested in the jury, with the power to embrace and declare the law, as received from the court, and the fact, in finding a general verdict. Certainty and uniformity in the administration and exercise of judicial power, which preserved the defendant's right to due process, presupposed that the jury received the law from the court, and acted in conformity with it. Where, in earlier times, the doctrine of attaint was the only way to reverse a judgment, exceptions could now be made to the ruling of a judge. If a statute allowed the jury to interpret the law, no exceptions would lie, for the law incorporated

$$
{ }^{55} \text { Ibid., } 187 .
$$


in the verdict would be unknowable. ${ }^{56}$ The exercise of judicial review by a jury, or the variable and inconclusive application of the law, would subvert the Constitution of the Commonwealth, which provided for a state court of last resort, under independent and unbiased judges, with power of review, and the authority to guide by precedents to assure uniformity in all courts.

Taking a narrow view of the statute, he stated that, if a jury were to try criminal cases "according to established forms and principles of $1 \mathrm{aw}, " 57$ they would be proceeding upon the familiar ground of the common law, in receiving the law from the court. He agreed that ambiguity in the words "try" and "decide by a general verdict" 58 might lead to the supposition that a jury could determine the law, and assess the constitutional validity of a statute, against the directions of the court. However, even the "broadest and most liberal view" 59 of the constitution, would find the statute unconstitutional, for the Legislature could not vest in other persons, whose duties were limited and temporary, the power of the judicial department to decide the law.

In separate opinions, Justices George T. Bigelow, Charles Dewey and Benjamin F. Thomas, all Whigs, the latter

${ }^{56}$ But see "The Changing Role of the Jury," 174, 181 n. 66: The problem of the jury's determination of the law could have been met by interrogating the jury, or by utilizing a reviewing court. These suggestions were made in 1847 and 1809 .
$57_{5}$ Gray 220.
${ }^{58}$ Ibia.
${ }^{59}$ Ibid., 222. 
two dissenting, insisted that it was the legislature's intent to change the rule of the common law as declared in Porter because of adverse criticism of the opinion in the community. Bigelow believed that a "true construction" of the statute must acknowledge the intent of the legislature to change the rule in Porter, but believed that it was not within the constitutional authority of the legislature to confer such a right on juries. 60 Neither Dewey nor Thomas regarded the statute as giving more than a carefully guarded and qualified power and right to the jury to depart from the instructions of the court in favour of the accused. Any intelligent and watchful judge would, they believed, know whether the jury had conformed to the court's opinion, and the party would be protected by bills of exception. But they had reservations about the statute. Though asserting that judges should have no opinion concerning its wisdom and expediency, Thomas ventured:

Whether the statute is in harmony with public policy, whether it renders less certain the conviction of offenders against the law, whether it gives to jurors a power for the exercise of which their previous training has not fitted them, are questions for the lawmaker.61

However, neither would deny the statute's constitutionality. Reviewing the changes in the system of jury trial, they recognized the contributions of legislation. Had not the legislature, said Thomas, used its power to ensure that juries were impartial and independent, and persons of character and intelligence? Indeed, had not the legislature

$$
60_{5} \text { Gray, } 251 . \quad 61_{5} \text { Gray, } 283 .
$$


declared the right of the jury to decide, at their discretion, both the law and the fact, in a law of 1807, in force until 1836, never tested by the courts, and only left out in the revised statutes, he believed, because it was a familiar rule requiring no affirmative legislation? Did not Commonwealth v. Kneeland concur with the statute; had not Justices wilde and Morton accepted that cases arise where the jury might assess the constitutionality of a legislative act? Yet Porter had rejected practice and usage, treating the matter as "one of abstract reason and speculation." 62 The Supreme court, he said, "on the verge of political discussion. . was on extremely dangerous ground." 63

The meaningful role which laymen had played in court proceedings was considerably restrained by the middle of the nineteenth century. As these cases demonstrate, the judicial arbitrators of orderly social process, no matter whether Democrat or Whig, determined that the people as jurors should no longer, as previously agreed upon, interpret questions of law, had contracted the role of the jury to the resolution of questions of fact. Having established control in civil cases, where, as Tocqueville had seen, a judge/jury partnership functioned as a major check on majoritarian despotism, the courts had extended their domination into criminal cases, molding a protective framework to preserve minorities from the people at large. Echoing Tocqueville's anxiety that juries might succumb to the subtle pressures

$$
625 \text { Gray, 283. } 63 \text { Ibid. , } 260 .
$$


and intimidations of majorities, which, generating a "germ of tyranny," contributed to the unpredictability and uncertainty of the legal system, the courts fixed boundaries upon the people's power as jurors to sanction the wrathful will of the majority. 
The Judiciary and the Political Authorities

In describing the operation of judicial review, Tocqueville wrote that a law, once censured in the courts, was not abolished, though it lost "a portion of its moral force"; it required "reiterated attacks of judicial functionaries" to accomplish its final destruction. He believed that legislation was protected from "wanton" assaults by the judiciary, for, when a judge contested a law "in an obscure debate on some particular case," the importance of his attack was generally concealed from the public's attention. Further, such assault necessarily required that the private interests of an individual must be linked with the dubious law in the course of Iitigation; judicial censorship over legislation therefore could never extend to all laws indiscriminately. 1

Yet, Tocqueville would later write that, "armed with the power of declaring the laws unconstitutional, the American magistrate perpetually interferes in political affairs" through the courts of justice, "by which the legal profession is enabled to control the democracy." 2 This

\footnotetext{
${ }^{1}$ Tocqueville, Democracy in America, I, 101-3. 2 Ibid., I, 178-9.
} 
contradiction meriting close consideration, the question is, did legislative, or judicial, standards of constitutional propriety prevail?

In The Federalist No. 78, Hamilton had claimed that the judiciary was designed as an "intermediate body" between the legislature, whose authority, as servant of the people, was limited by the Constitution, and the people, in whom sovereignty lay. Where the decisions of the legislature, proclaimed in its statutes, violated the will of the people, as declared in the Constitution, it became the duty of the courts to declare such actions void, for the interpretation of the law was the peculiar province of jurists. This supposed no superiority of the judicial over the legislative power, for both were agents of the people. Instead, it advanced a "more rational interpretation" of the Constitution, which had no clear provisions regarding the resolution of constitutional conflicts. ${ }^{3}$

An alternative to Hamilton's view that the judiciary was the ultimate arbiter of constitutionality, echoed in Tocqueville's declaration that the courts, far from imposing their construction of the constitution on others, merely applied their evaluation to cases before them, was claimed by Jackson in his bank veto of July, 1832. 4 His conception of presidential authority, with its contention that the

${ }^{3}$ Clinton Rossiter, ed., The Federalist Papers, 467. 4 Richardson, Messages and Papers of the Presidents, II, p. 582 . 
executive was not obliged to recognize the validity of judicial decisions, proceeded from his right to exercise a separate judgment upon the widom and constitutionality of a proposed law, and could not be seriously challenged. However, linked as it was with the bank recharter issue, it raised storms of controversy.

Early nineteenth century courts had tended to leave to the electoral and legislative processes the resolution of conflicts between organized social interest groups, and few had reviewed constitutional matters of more than individual or local interest. Their perceived purpose, which Hamilton had articulated, was to protect the people, a cohesive body possessing shared beliefs about the nature of republican government, from legislatures which betrayed their trust and violated the constitution. 5

With the advent of Jacksonian democracy, an enlarged electorate presupposing a more responsible selection, the prospect of legislative betrayal in an increasingly democratic society seemed more remote. Further, judges acknowledged that constitutional provisions were often inexact. This necessary condition of a flexible system of government that could adjust to the changing needs of society meant, however, that the exercise of judicial discretion in the invalidation of legislative acts, which involved a value

${ }^{5}$ William E. Nelson, "Changing Conceptions of Judicial Review," University of Pennsylvania Law Review, 120 (1972), 1177. 
judgment as political as it was legal, could be perceived as anti-democratic. Yet, courts could no longer ignore the re-evaluation of legislative political determinations upon divisive social conflicts between organized groups, as these cases came increasingly before them.

In this new context, where courts were more aware of the public interest in, and significance of, their decisions, respect for the legislature, according to Leonard Levy, was a "maxim" of the Shaw court in Massachusetts. 6 only two cases of judicial intervention within the province of the political authorities occurred in the ten-year period, 1835-45, and these both concerned local government.

In the first case, City of Boston v. Shaw (1840), Justice Putnam found invalid a by-law of the city of Boston. The ordinance had required that every landowner who used a city sewer should be assessed for its construction, according to the immediate prior evaluation made of his property. Though the power was given by charter to the city to lay and assess taxes and make by-laws, and it was reasonable for the city to construct common sewers, when he considered the mode of assessment he believed it to be unequal and unreasonable, and therefore unjust. For the apportionment to be fair, he suggested, it ought to be made on the value of the land

\footnotetext{
${ }^{6}$ Levy, The Law of the Commonwealth and Chief Justice Shaw, 267.
} 
independently of the buildings, and should be settled at the time of construction. 7

In Worcester v. Western Railroad Corporation (1842), Chief Justice Shaw, using the eminent domain power as an instrument to encourage economic growth, extended a tax immunity for a so-called public work. The city had claimed that, although the railroad's right of way was exempt from taxes, its buildings, lying in whole or in part within the limits of the right of way, were not. After examining the railroad's charter, Shaw ruled that the corporation, established "for the public use and benefit," held its personal property "in trust for the public.. . for a well-defined public object," and that, because the legislature had reserved to itself certain powers and controls, it was not a private corporation in the contemplation of the law, and, as such, like bridges and turnpikes, was exempt from taxes. 8 No limit to this exemption was written into the charter, therefore all buildings "used to promote the purposes contemplated by the act," and all lands purchased by the corporation were immune "as appropriated to public use," unless they were reasonably incident to the support of the railroad, or to its use as a common carrier. 9

Perhaps at issue, also, was concern that localism could result in inconsistent bases of evaluation and/or competition for revenue among taxing towns, which could

\footnotetext{
71 Metcalf, $130 . \quad 84$ Metcalf, 566.

$9^{\text {Ibid., } 568 .}$
} 
seriously impede the development of facilities critical to the general economy. These two cases reveal that the Massachusetts court had decided to foster economic changes on their terms; that, within the boundaries of constitutional safeguards, the law would protect and aid individuals in their private planning. ${ }^{10}$ what appears significant in the later case is the community consensus, a belief shared by both legislature and judiciary, that legal doctrines should delegate power and resources to private entrepreneurs to promote economic growth, a view of public policy that was highly pragmatic.

The predominant characteristic of judicial review in Pennsylvania in this period, on the other hand, is a marked antagonism towards the legislature, which had asserted its dominance by interfering with judicial tenure. The subject was particularly sensitive. Just before the new Constitution of 1838 went into effect, the Chief Justice was persuaded by his friends to resign, and was re-appointed by the outgoing governor, securing the longest term that the new law allowed. 11

Leib v. Commonwealth (May, 1840) concerned an associate judge of the Court of Common Pleas who had duplicated

${ }^{10}$ James $W$. Hurst, Law and the Conditions of Freedom in Nineteenth Century United States (Madison, 1956), 52, 25: "A kind of insistence on equal protection of the law, that a particular individual should not be made to bear out of his own resources the cost of community benefit."

${ }^{11}$ Howard Knott, Dictionary of American Biography, IV, 
this procedure. At issue was the attempt by the legislature to initiate popular control of the bench by substituting a limited commission for life tenure. The lower court had determined that, according to the amended constitution of the state, Leib had no authority to exercise the office of associate judge after January 1, 1839. The decision of the court was delivered by Justice Sergeant, a Democrat who would strongly oppose the amendment to elect judges and resign in $1843 .^{12}$ He denied that the court below had jurisdiction under an act of June, 1836, whereby power was given to the courts of common pleas to hear personal suits "within their respective counties." 13 Holding that an associate judge of the Court of Common Pleas was not a county officer within the meaning of the act, which embraced instead "officers inferior in grade and consequence," but was, as described in the amended constitution of 1838, an "associate judge of the state," he regretted the finding that Leib no longer held his commission in January $1,1839.14$ The amendment concerning associate justices, differing from that

\section{Julian P. Boyd, Ibid., VIII, ii, 590.}

139 watts, $220(1840)$. This court was Leib's own. His appointment by the out-going governor on December 29 , 1838, followed upon a vacancy created - when Daniel Yost resigned, after holding the commission for 30 years. Judge Porter, the president of the court, observed that, "although it is not contended that the respondent had anything to do with procuring his resignation, yet still, for that resignation there would have been no vacancy to fill." (Ibid..) 215). 
affecting president judges, ${ }^{15}$ made no express qualifications regarding the time at which cormissions had been issued.

Nor had the legislature the power to arrange by statute, and then re-arrange by another, the classification of associate justices as to tenure, for this was "inconsistent with the constitution, and fraught with inconvenience and hazard to the community."16 Therefore, he considered as valid the act of June, 1839, which had systematized the tenure of associate justices according to the priority of the dates of their commissions as they stood on January, 1839, and under which Leib was designated to remain in office until February, 1843. 17 The supplementary act of March, 1840, which graded commissions according to the date of the adoption of the constitution, which the legislature chose to recognize as October 9, 1838, and which terminated Leib's term in February, 1840, now past, Sergeant considered to be unconstitutional. Further, the earlier statute was passed during the legislature's first session according to a provision

${ }^{15}$ The precedent for the finding in the lower court was Commonwealth v. Collins, 8 Watts 331, (1839), where Justice Kennedy had held that the new constitution had been adopted when the speaker of the senate publicly announced its ratification, which had occurred on December 11, 1838. (Justice Huston, in a strong dissent, had determined the date of adoption to be January $1,1839$.$) President judges appointed$ between the adoption of the constitution and January 1, 1839, therefore lost their commissions on the latter date.

16 watts, 227.

${ }^{17}$ Ibid., thereby ranking Leib according to the seniority of the commission as held by his predecessor, Yost. Actually, Leib took the oath of office on December $31,1838$. 
required by the new constitution, which a subsequent legislature could not constitutionally do. ${ }^{18}$

In Norman v. Heist (1843), Chief Justice Gibson construed an act so as to set limits to legislative omnipotence, but stopped short of voiding it. In this case, by an act passed in 1841, the children of an illegitimate son were declared to be "able and capable" of inheriting their grandmother's property. ${ }^{19}$ As she had died in 1840 without making a will, her estate had passed to her brothers by the intestate laws, though her grandchildren had continued to reside there. Stating that the latter had misconstrued the effect of the statute, which was merely enabling, and that the property might yet descend to them in default of issue of the brothers, Gibson denounced the act as "an ex post facto rescript or decree made for the occasion."

Retracting his former statements regarding judicial review, ${ }^{20}$ the Chief Justice declared that, as the estate was

189 watts, 226-7, for it is "a delegation to that specific body of a portion of the sovereign power of the people."

${ }^{19} 5$ watts and Sergeant, 173 (1843).

${ }^{20}$ As a judge in Pennsylvania in 1825, Gibson had contested the exercise of judicial review upon legislative acts, which he perceived as expressions of the sovereign power of the people, according to the "postulate, in the theory of our government, and the very basis of the superstructure, that the people are wise, virtuous and competent to manage their own affairs" - Eakin v. Raub, 12 Sargent and Rawle, 330 (1825), (emphasis in text) quoted in Nelson, "Changing Conceptions of Judicial Review," 1181. Gibson had questioned whether judicial interpretation of legislation with reference to constitutional texts involved merely legal determinations, for repugnance to the constitution was not always "self-evident"; the exercise of "political" discretion must be admitted. 
lawfully vested in the plaintiffs as heirs of their intestate sister, by no "act of despotic power" could the legislature deprive them of their property, with or without compensation:

Not only because the general provision in the bill of rights was deemed sufficiently explicit for that, but because it was expected that no Legislature would be so regardless of right as to attempt it. Were this reasonable expectation to be disappointed, it would become our plain and imperative duty to obey the immediate and paramount will of the people expressed . . . in the adoption of the constitution, rather than the repugnant will of their delegates acting under a restricted, but transcended authority.

The right of property, he said, had no foundation or security but the law, and "when the Legislature shall successfully attempt to overturn it, even in a single instance, the liberty of the citizen shall be no more." 21

Though no statute was invalidated in clippinger v. Hepbaugh (1843), the case offered another opportunity for judicial observations upon legislative ethics. In reversing a verdict whereby an attorney, in the court below, had successfully sued for services rendered in procuring a private act on a contingency basis, Justice Rogers held that, should the court give "legal sanction" to contracts for such services, it would be "impossible to foretell the train of evils of which it may be the prolific parent." Already the legislature had been "contaminated by sinister and improper influences. - . There is at least a wide-spread and growing suspicion of legislative integrity, which of itself is 
an evil of no little magnitude." He believed that contracts for contingent fees should be illegal, to avoid improper tampering with the people's representatives, for "many painful examples" had already appeared. 22

In Commonwealth V. Mann (1843) the court set aside two legislative acts which had reduced the salary of a president judge of the court of common pleas subsequent to his appointment. Finding that, under Article 5, Section 2, of the Constitution, compensation for justices should not be diminished during their tenure, Justice Rogers rejected the claim made by the state's treasurer that the legislature had the power to withdraw a gratuitous increase in salary, and, to create additional revenue, to extinguish the state's debts by withholding taxes assessed upon salaries of officers of the Commonwealth. The case, he said, raised matters of "the most grave and important character, involving the construction of the fundamental principles of government." 23 His sincere respect for a coordinate branch made him reluctant to question a legislative exposition of the Constitution, but history had taught him to guard the rights of the citizen from the "injustices and gradual encroachments of those to whom they were compelled to intrust the management of their affairs"; experience had taught him that there was no better way of destroying the liberties of the people than by the government's utilization of a "venal, time-serving, 
timid and subservient judiciary."24 Using "copious" extracts, for which he knew he would be excused, by able commentators of the Constitution on the second section of the fifth article, he had surely proved that "a power over a man's subsistence amounts to a power over his will," and therefore:

To effect a favorite object of legislative ambition, or to gratify the vindictive feelings occasioned by the phrenzy and madness of party, a successful resort may be had, by such means, to the judicial tribunals of the country. 25

Warming to his subject, he declared that, where the departments in a government were separate, the:

Judiciary, from the nature of its functions, will always be the least dangerous to the political rights of the Constitution, because it will be least in a capacity to annoy and injure them. . . It may be truly said to have neither force nor will but merely judgment. 26

It had no influence over sword nor purse, and:

No direction of either the strength or the wealth of society, and can take no active resolution whatever . . and though individual oppression may now and then proceed from courts of justice, the general liberty of the people can never be endangered from that quarter . . . so long as the judiciary remains truly distinct from both the legislature and the executive.

If, because of its "natural feebleness," the judiciary were in continual jeopardy of being overpowered, "permanent tenure of judicial offices, and an invariable compensation, incapable of diminution," would enable it to be considered as a "bulwark" of a limited constitution. 27 This court,

$$
\begin{aligned}
& 24 \text { Ibid., } 406(1843) . \quad 25 \text { Ibid., 406-8. } \\
& 26 \text { Ibid., 408-9, emphasis in original. } \\
& 27 \text { Watts and Sergeant, 410-11 (1843). }
\end{aligned}
$$


then would not betray its trust by refusing "to interpose to prevent injustice, whether arising from a wilful, deliberate and wicked invasion of the constitution," or from a mistaken construction of the legislative authority. The court would meet on the threshold the first attempt at encroachment by voiding these two acts.

Although the justice had things to say about infamous despotism, "the limits of a judicial opinion" would not allow him to pursue this theme. ${ }^{28}$

Putting aside old scruples about judicial review, for which, instead, justifications were diligently delivered, the court had censured legislative interference with judicial function, contested legislative omnipotence, and warned against legislative impiety. The citizen would be sheltered from political majoritarianism.

By 1835, the Supreme Court in Tennessee was no longer prepared to tolerate what it considered to be an extravagant accretion of power by the legislature: "We are aware of what is every day urged, the omnipotence of the legislature; that whatever is not forbidden by the Constitution is left open for that body to do," Justice Peck said in that year. He denounced legislative actions which "step[ped] in the place of judicial authority." 29 The cases in the decade following reveal the development of constitutional doctrines 28 Ibid., 421. ${ }^{29}$ Richardson v. Wilson, 8 Yerger 79-80 (1835). The case involved a plea for alimony following a legislative divorce. 
as principles for the evaluation of legislation, so as to curb legislative authority.

Utilizing the doctrine of natural rights, Justice Green, in Jones' Heirs V. Perry (1836), voided a private act which had authorized a guardian of infants to sell land against a parent's indebtedness. The defendant's counsel had claimed that, by the "law of the land," 30 real estate was subject to payment of liabilities which descended to heirs. Just as title could be divested to settle obligations by order of the constitution, so might the legislature pass a private act authorizing a remedy for a debt. He believed that the heirs, though minors, were of age to understand and consent to the sale, and that the act of limitations protected the defendant, who had been in possession under the deed of sale for more than seven years. The justice held that the private act of 1825 was an exercise of judicial authority which deprived the complainants of their property without the judgment of their peers or the operation of the law of the land. By the sixth article of the constitution, which vested judicial power in the courts, the legislature was restrained from encroaching upon the jurisdiction of a coordinate department. "In substance," the act of 1825 was a judicial decree which adjudged the existence of a debt, and determined its discharge by means of a law neither uniform, universal nor permanent in 
character. 31 The language of the bill of rights forbade the enactment of any law by which an individual's rights were abridged. Only by the "judgment of his peers or the law of the land" could he be deprived of his life, liberty or property; the term "law of the land" implied a "general and public law, operating equally upon every member of the community." 32

It was "settled law" in Tennessee, Green declared, that creditors of an ancestor had no lien upon the lands descended to an heir. ${ }^{33}$ Though tedious, the course of law was available for those to whom debts were owing. Neither was an infant capable of exercising discreet judgment concerning his possessions; he could not be an agent in their sale. Though the defendants had failed to register the deed of sale until 1829, their possession there-under from 1826 barred only the eldest complainant, who was of age within the seven-year limit established by statute, from recovery, and the title must revert to the others.

It was the intention of the court, said Green, to "check the assumption of an excess power" by the legislature promptly, whenever a case occurred, and so "accustom" the members to the restraints of the constitution; therefore, while on the one hand, the courts:

Ought to entertain for the legislature the highest respect, and to decide against their acts only from the

$$
\begin{aligned}
& 31 \text { Ibid., 70. } 3210 \text { Yerger, } 71 . \\
& 34 \text { Ibid., } 71 .
\end{aligned}
$$


clearest convictions of duty, on the other hand, where they are clearly satisfied the constitution is violated, they have no alternative but to declare that such act of assembly is not law. 34

In Buddv. State (1842), the court again annulled a statute deemed partial, this time in the divisive area of bank charters. In the court below, Budd, employed as "clerk of the individual ledger," 35 was found guilty of making a false entry with a view to defraud the Union Bank, incorporated by statute in 1832 . Justice Reese, referring to the 22nd section of the act, by which it was made a criminal offence for "officers, agents and servants" to attempt to cheat the bank, held that, as "clerks" were not specifically designated, they were not "properly comprehended and described"; that the term clerk was "of such varied import, that we are not at 1 iberty to hold that 'clerk,' and especially 'clerk of the individual ledger,' is equivalent to officer, agent or servant."36 Neither had the indictment specifically indicated that Budd was employed by the bank, and therefore he was not properly charged.

Despite having overturned the judgment, Reese proceeded to find a:

Graver and weightier question . . whether the act of 1832, which created a felony in relation to officers, servants and agents of the Union Bank only, could be considered as "the law of the land" consistent with the bill of rights. 37

Citing Jones' Heirs, he held that the protection intended to

${ }^{3.4}$ Ibid. , 71.

$36_{3}$ Humphreys, 489 .
$35_{3}$ Humphreys, 488 .

37 Ibid., 490. 
be extended to individuals by the bill of rights could not be effective where their liberty or property might be exposed to the operation of a partial law. He believed that the bank could find other effective safeguards which were consistent with public liberty. "As to the coordinate department," he added:

To whose enactment we feel unable to give effect, we cheerfully acknowledge that their intelligence, and numbers, and high motives and sanctions under which they, too act, impose upon us the obligation, when comparing the result of any deliberation of theirs with the paramount law which governs us all, to be well satisfied that in declaring a statute invalid and void we but obey the mandate of the constitution. 38

In 1844 , John H. White, special judge, in Governor v. Porter and Sureties, invoked constitutional restrictions upon a statute which undertook to construe an earlier act. ${ }^{39}$ Holding that, "as the Constitution is the paramount law," whereby each department of government was prohibited from "exercising any of the powers properly belonging to any of the others," he declared that the legislature could not destroy the checks and balances of government by enacting a law which, neither repealing nor replacing an earlier statute, "decide[d] upon its construction." 40

According to the conditions of the first act, of 1835 , Porter (a sheriff) had posted a bond in the county court for the collection and payment of state taxes for the years 1840 and 1841. A subsequent act, of 1839-40, required that bonds 38 Ibid., 493. ${ }_{40}^{39} 5$ Humphreys, 167.
5 Humphreys, 168. 
were to be executed as per the act of 1835, "which shall be construed to require said bonds to be given hereafter every year." 41 porter was indicted in the court below for default and delinquency for the year 1841, and his demurrer to the plea was sustained.

Asserting that deficiencies in the drafting of both statutes endangered the security of the public revenue by permitting it to be plundered by a public officer, Judge White declined to construe them liberally so as to render them effectual. He therefore voided the later act, declared the 1835 act as effective in its terms, reversed the lower court's ruling and overruled the demurrer. 42

In Green V. Allen (1844), the court again stepped in to overturn special legislation considered arbitrary in a suit which, on appeal from the chancery court, presented for the first time in Tennessee the matter of donations to charity.

The case concerned a will which, by its terms, required the executor to sell all property, and to give a quarter of the proceeds to the Tennessee Annual Conference of the Methodist Episcopal Church (an unincorporated society) for the benefit of its schools and missions, and "to be otherwise disposed of " as the society thought fit. ${ }^{43}$ In an

\section{Ibid., 168.}

42 Ibid., 168-9. Thereby depriving the crafty sheriff of the loophole perceived in the 1839-40 statute.

435 Humphreys, 170 . 
elaborate and lengthy opinion, in which he investigated the medieval and colonial backgrounds of bequests, 44 to show that donations for charitable and pious purposes had long been subject to abuse, Justice Turley held that a Tennessee court of chancery had no jurisdiction over a trust "when it is mixed up with general moral duty . . it must be of such a tangible nature that the court can deal with it." 45 There was no power in such a court similar to that of the Lord Chancellor in England who, as an agent of the crown, exercised personal jurisdiction over the use and administration of bequests considered general and indefinite; this would be inconsistent with the constitution of the state as being a "branch of executive prerogative." 46 Further, as a charity "must stand or fall as it was found to exist at the death of the testator, if it were not then legal and valid, no subsequent statute of the legislature can make it good." 47 The appointment, under a special act of 1841, of trustees to receive the bequest on behalf of the Methodist Episcopal Society membership, was not only too late, but was an exercise of judicial function. Indeed, the act was unconstitutional and void under Article 7, section 11, which prohibited the passage of partial laws for the benefit of

${ }^{44}$ Ibid., 179, 189: an "investigation alarming in its extent and perplexity" for searching for some principles of chancery jurisdiction was "like looking for a live body in an Egyptian catacomb."
$45_{5}$ Humphreys, 194.
${ }^{46}$ Ibid., 206.
${ }^{47}$ Ibid., 209. 
particular individuals. He could not, therefore, sustain the validity of the bequest, which was declared unenforceable. 48

While articulating justifications for judicial review, the Tennessee court had used constitutional precepts and procedural formulae to defeat special legislation where, it stated, arbitrary legislative power had led to abuses, confusion and uncertainty. The New York court, in this period, expanded the overview of legislation, applying traditional doctrines and forms to challenge statutes deemed tainted with tyranny, and developing rules of interpretation to maximize their discretion and authority. The first three cases deal with the eminent domain power, which had been utilized aggressively by the legislature for public improvement.

The first comprehended the principle of compensation and the concerns of state economic planners for low costs in the development of water transportation. In People v. Canal Appraisers (1835), the owner of a millsite impaired by the construction of the Erie Canal, having proved his title by jury verdict in the court below, sued for compensation for injuries resulting from the diversion of water into a sloop lock. The defendants' counsel claimed that, by an act passed in 1792, the state, exercising its sovereign power, had granted to the canal company as a "free gift" the stream upon which the millsite stood. 49 As the common law

$$
{ }^{48} \text { Ibid., 210. } \quad 4913 \text { Wendell, } 363 .
$$


principle with regard to navigable rivers did not apply in the state, owners of adjoining banks could not be regarded as holding title to the streams. Justice Jacob Sutherland, declining to discuss whether the English common law test were applicable "to the nature and extent of our inland streams," 50 held that, though the legislature "appear to have overlooked or disregarded" the principle of the common law in granting islands to other individuals, as separate and distinct from the land on their respective banks, it was his contention that the relator was the owner to the middle of the stream. 51 Therefore, "when private property is destroyed, and its beneficial enjoyment is essentially impaired in the prosecution of public works, the owner is entitled to compensation." Damages must be appraised for the southern half of the stream. ${ }^{52}$

In 1839, the court again enunciated firm principles for the evaluation of legislation involving the eminent domain power. In The Matter of John and Cherry Streets, an 1818 statute had established the procedure whereby the City of New York might improve any street or public place, the court reviewing the estimates and assessments made by

${ }^{50}$ Ibid., 371. If the rivers were subject to the ebb and flow of the tide, they were regarded as non-navigable under the test of the English common law. There were, in contrast to the English isle, navigable fresh water rivers in America, in which the tide did not ebb and flow. In 1836, keeping a finger on the pulse of change, the court rejected the common law rule: Canal Appraisers v. The People, 17 Wendell, 571.

$$
{ }^{51} \text { Ibid.. } 372 . \quad 52 \text { Ibid., } 373 .
$$


court-appointed commissioners for the Corporation and any objection thereto. Justice Cowen, observing that it was difficult for a judge to dismiss as unfair estimates by experts in the field, where present and future valuations had to be considered, stated that he would not reject a report where the proceedings were regular, and where "no error in principle" were evident. 53 He had found no adequate ground for the reconsideration of damage awards to the individual objectors in the case, but questioned whether the Corporation might legally take as its own, and for a nominal price, a triangular piece of property belonging to unknown owners, in the closing and straightening of John street, and narrow strips of land, also of owners unknown, from which the proposed new Cherry street receded. Was not this:

Incompatible with that part of the state constitution which declared that no person shall be deprived of life, liberty or property, without due process of law . . . unless it were a taking of property for public use, or, in other words 54 an exercise of the national right of eminent domain? 54

The common law recognized title of owners adjacent to public highways to the centre of the road, subject only to the public right of way. Therefore, where a street were discontinued in part or in whole, the rules applied. Consequently, as a statute was void which authorized the transfer of property without the consent of the owners, he referred the report back to the commissioners for reconsideration and

5319 Wendell, 670. ${ }^{54}$ Ibid., 666 . 
correction by assigning the property awarded to the Corporation to the adjacent property owners. 55

In 1843, in the face of a sharp dissent by Chief Justice Samuel Nelson, the court rejected the orthodox view of public purpose in the invasion of property through the power of eminent domain. In Taylor v. Porter and Ford, Justice Bronson struck down as unconstitutional a colonial statute passed in 1772, which, according to Nelson, had been "in active operation ever since," 56 by which landowners were able to build private roads through others' property, with damages assessed. Utilizing the doctrine of natural rights, whereby the people, who alone had absolute sovereignty, could not be deprived of their property except by "the law of the land" (which, according to coke and Kent, meant "due process of law"57), he limited the exercise of legislative authority to "such powers as have been delegated to it. . . Neither liberty nor property, except when forfeited by crime, or when the latter is taken for public use, falls within the scope of the power." 58

Though it was a "grave matter" to declare an act of the legislature unconstitutional, 59 the judiciary would

55 Ibid., 677. Besides, he said, although the Corporation had "always sold [property taken] to the adjacent owners at the nominal prices which they gave," under the principle of eminent domain, any municipal court could become "legal purchasers on summary appraisal, and then sell out to individuals," perhaps third parties.
$56_{4} \mathrm{Hill}, 152$.
${ }^{57}$ Ibid., 146.
${ }^{58}$ Ibid., 145.
${ }^{59}$ Ibid., 143. 
decide whether public purpose adhered to the taking of private property. He feared that there was otherwise no constitutional barrier to uncompensated takings: "If the power exists to take the property of one man without his consent and transfer it to another, it may be exercised without any reference to the question of compensation." 60

As Justice Nelson's dissent suggests, the court had rejected the hitherto utilitarian justification for the use of the eminent domain power:

Works of this nature are indispensible to the prosperity of the country. . . . So intimately are they interwoven with individual enterprise and the public welfare that their establishment and regulation have hitherto been regarded as an essential branch of internal police. 61

By creating a distinction between public and private appropriations under this power, the court gave notice that legislatively authorized acquisitions would no longer be upheld simply because they furthered the state's economic improvement. By means of "the law of the land" and "natural rights," the court had reversed its earlier trend of support for legislative encouragement of economic growth through the use of the doctrine of eminent domain. What is significant about this case is the development of a substantive as well as a procedural concept of due process: "The legislative power of this state does not reach to such an unwarrantable

$$
\begin{aligned}
& { }^{60} \text { Ibid., } 148 . \\
& { }^{61} \text { Ibid., } 150 .
\end{aligned}
$$


extent." 62 How striking a vindication of judicial review of "public use," as against the legislative view.

In People v. Kane, the court, in 1840, moving to other matters, rejected an attempt by the City of Albany to assert local political autonomy by exercising its power over that of the governor of the state. Chief Justice Nelson, a conservative Democrat who had participated in the New York Constitutional Convention of 1821,63 held that a legislative act of 1826, which gave to the Common Council of Albany the power to appoint police justices, was "clearly in conflict with the 7 th section of the 4 th Article of the Constitution," as adopted by the people in 1822, which provided that all judicial officers were to be appointed by the governor and senate. As the functions of police justices were "wholly of a judicial character," they were to be appointed as the Constitution directed, 64 and Kane, named by the Council of the City to the position in 1838, had "intruded into the office." 65

This challenge to a relatively old statute, which had stood for 14 years, suggests that the court was adopting a new, more rigorous attitude towards the overview of legislation. In 1841, the court, per the Chief Justice, held that an act of the legislature of 1814 would have been null and

$62_{4} \mathrm{Hill}, 145$.

63 Robert E. Cushman, Dictionary of American Biography, VII, 411.

${ }^{64} 23$ Wendell, $417 . \quad 65$ Ibid., 414. 
void as against the complainants had they not deprived themselves of the right to object to its constitutionality. In Van Hook v. Whitlock, creditors of an insurance company incorporated in 1805, sued the stockholders, who were under individual liability, for debts contracted prior to the passage of an act of 1814, whereby, upon their insolvency, insurance companies were declared exempt from personal liability. Had the complainants not accepted the dividends, amounting to 51 percent of the debts, after the dissolution of the company in 1814, the act of that year would have been in violation of the Constitution of the United States as impairing the obligation of contracts. 66

In Purdy v. People, in 1842, on error from the Supreme Court, an act of May, 1840, which altered the charter of the City of New York, succumbed to the constitutional test by a narrow majority in the court for the correction of Errors. 67 Four senators, speaking for that predominantly Democratic body, and against the Chancellor, held that the constitution of the state, in Article 7, Section 9, required the assent of two-thirds of the members of each branch to alter or renew "any body politic or corporate." 68 Therefore, the act "For the Better Organization of the Criminal courts of the

6626 Wendell, 43.

${ }^{67}$ At this time, under the constitution of 1821 , it was New York's highest court, which consisted of the president of the Senate, the senators, the Chancellor and the justices of the Supreme Court.

$68_{4}$ Hill, 393. 
City," which excluded the aldermen from sitting as judges of the Court of General Sessions, and was passed as a simple majority bill, was unconstitutional. Denying the Chancellor's claim that municipal corporations, as public corporations, were not embraced by the constitutional provision, which was intended to guard against the "too rapid multiplication of bank charters and the legislative corruption which their creation induced," the court called for a return to the:

old and revered doctrine of strict construction - the only sound and safe doctrine for the government of either judges or legislators. . . Nothing can be more dangerous to our free institutions, or the rights of the people, than to encourage doubtful interpretations of the Constitution, contrary to its more plain and natural import, as understood by the great body of its readers. 69

In 1845 , the court, challenging the reformist tendencies of the legislature, overturned its political judgment on the sensitive issue of banks in De Bow v. the People. The defendant had been convicted in the court below of passing counterfeit bank notes with the intent to defraud the Bank of Warsaw. His counsel had charged that no such bank existed in law, as the general Banking Act of 1838, under which the associates had intended to become operative as the Bank of Warsaw, had not been passed by a vote of twothirds of the members of the legislature, and was therefore invalid. Bronson, now Chief Justice, held that the defendant was improperly convicted, as there was no such legal 
being as the Bank of Warsaw. Citing Purdy as precedent, he declared that the two-thirds clause extended to all corporations, as the constitution, "in unequivocal terms," had declared. The safety of free institutions, he believed, depended upon a "strict adherence to the fundamental law, whatever we may think of the wisdom and expediency of its provisions"; he would censure any attempt to disregard the "explicit language" in favour of what some might choose to consider the "intent and meaning" of the constitution. 70

This "strict adherence" to constitutional safeguards caused Bronson, in People v. Warner (1845), to declare an act of 1843, which created the office of clerk of the court of Common Pleas for the city and county of New York, null and void. The constitution, Article 4, Section 8, of 1821, he declared, had directed that the position should be filled as a dual role, by the elected clerk of the city and county. As the new office would be filled by the court, the electors would be deprived of their right: "If the office may be divided, and the duties assigned to two officers, both must be chosen by the electors of the county. No other rule will give full effect to the constitution." 71

By the time the court ruled on Quakenbush v. Danks (1845), the use of legal procedures to maximize judicial authority had become settled technique. The case concerned a sheriff's deputy who had been directed, in 1843, to

$$
701 \text { Denio, } 13,18 . \quad 717 \mathrm{Hill}, 82 .
$$


recover from Danks a debt for which he had been judged liable in 1837. For this reason, his horse and harness, the only property not covered by the exemption laws passed prior to 1842, were taken, though he insisted that they were necessary to the support of his family. In the court below, his counsel had claimed that under the new Exemption Law of 1842, all of Danks' property was exempt from sale on execution, and the jury returned a verdict for him. Bronson, overturning this finding, held that the Exemption Law of 1842, "in general words," was broad enough to cover debts contracted prior to its passage, but it ought not to be applied to the case in hand, otherwise "it may be a moral, but it is no longer the legal duty of the debtor to pay." A statute should not be construed retrospectively; the "rule of justice and honesty" required that every law should, if possible, be so interpreted that no wrong would be done. Therefore, property subject to execution at the time the debt was contracted must remain subject to execution until the debt was paid. 72 The legislature "cannot legislate backwards and annul the force of prior obligations," therefore the Exemption Law of 1842, when applied to past transactions, must be set aside. 73

"In the United States," Tocqueville had written, "the Constitution governs the legislature as much as the private citizen"; legal tribunals obey the Constitution "in

$$
721 \text { Denio, } 131 . \quad 73 \text { Ibid., } 133 .
$$


preference to any law."74 Though reflecting a current understanding of the bench's power to strike down legislative acts, Tocqueville did not undervalue its potential to subvert legislative supremacy. Aware that burgeoning partisan sentiment gave to their decisions a grave and delicate character, the courts, claiming allegiance to the Constitution as the supreme law of the land, developed doctrines for the evaluation of legislation which placed substantive restraints on legislative power. The great principles of republican government, higher law and the Bills of Rights, provided authoritative legal precepts to temper perceived crude and arbitrary legislation. Where the protection of minority rights through judicial review promoted progress according to the judicial conception of social order and harmony, the judiciary functioned as a restraint upon Tocqueville's majoritarian tyranny. Vested interests in property, politics and economic enterprise were safeguarded by the conservative bar to keep the nation loyal to their notion of America's social identity. 


\section{The Judiciary and Individual Rights}

Tocqueville's majoritarian thesis stresses that the moral authority of the many could, with its subtle conforming pressures, restrain the individual from the development and expression of novel ideas and uncommon beliefs; that the presiding sense of the community, cherishing its creed, would correct and discipline unorthodox opinion, admitting no dissidence. Only humanity, reason and justice could shelter the insubordinate freethinker in the moral world, and, in the political world, vested rights. ${ }^{1}$

Yet, if the Constitution withdrew from partisan debate certain agreed upon essentials, and these, inscribed in the Declarations of Rights, were defended against encroachment, was the individual as secure in his civil liberties within the institutional sphere of judicial authority as Tocqueville suggested? As usual, he offered a shrewd insight into the nature and creative potentialities of the judicial function: "Lawyers are attached to public order beyond every other consideration." 2 This basic assumption

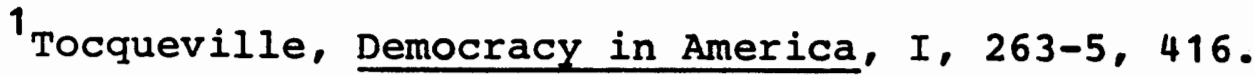
2 Ibid., 275.
} 
determines the following four cases. In the first, a breach of the spiritual peace was condemned lest it place the harmony of society in jeopardy.

Abner Kneeland is described by a biographer as a refined and courteous man, of sincerity, courage and purity of character. Sometime Baptist and Universalist minister, translator of the New Testament, and editor of several Christian papers which championed liberal notions, his religious views had, by 1830 , veered towards the extreme, and he expounded pantheistic beliefs from the podium of the First Society of Free Inquirers. ${ }^{3}$ He was a Jackson man whose lectures both in person and print drew large audiences. ${ }^{4}$ In early 1834, under an act against blasphemy passed in 1782, Kneeland was indicted for having "unlawfully and wickedly" published a "scandalous, impious, obscene, blasphemous and profane libel" on the existence of God in the Boston Investigator. Contained in a public letter, which he had written to a Universalist periodical, it said in part: "Universalists believe in god which I do not; but believe that their god, with all his moral attributes . . is nothing more than a chimera of their own imagination." Upon conviction Kneeland appealed, enduring three trials before Justices Putnam and Wilde, yet remaining in the

${ }^{3}$ William H. Allison, Dictionary of American Biography, $v$, ii, 457-8. Shaw, 43.

4 Levy, The Law of the Commonwealth and Chief Justice 
shadow of prison. He made a final plea to the full bench of the Supreme Judicial Court, and his case was heard in 1836.5 Acting as his own counsel, Kneeland protested that the public letter addressed to the Universalists did not constitute a denial of God within the meaning of the statute. He had, he said, simply expressed a disbelief, or doubt, in the creed of the Universalists; he was himself a pantheist. ${ }^{6}$ He was satisfied, however, that the act of 1782 was unconstitutional, for it violated Article 2 of the Declaration of Rights which safeguarded a subject in his "religious professions and sentiments"; it infringed Article 16, which guaranteed the right to propagate sentiments in the press, unless slanderous; it impaired the nation's law of naturalization which gave to all faiths the rights of citizens.

Expressing regret that the defendant had chosen to represent himself, ${ }^{7}$ to the derogation of his case, Chief Justice Shaw, for the predominantly Unitarian court, sustained Kneeland's conviction. Though the two-year delay in handing down the decision had been occasioned by the "intrinsic difficulty attending some of the questions raised in the

\section{${ }^{5} 20$ Pick, 206 (1838).}

6 Ibid., 207. Kneeland was mindful, it appears, of the traditional rejection of the atheist's testimony.

7'Ibid., 266: Morton's dissent was based on Wilde's instructions to the jury in the lower court, which he considered to be a mistaken view of the law. He regretted that Kneeland, "unversed in some of the distinctions and principles of criminal law," had failed to make use of a "technical form," which would at least have left the door open for another trial. 
case, and a difference of opinion among the judges," 8 he believed that there was now "no doubt" that kneeland's public letter constituted blasphemy within the meaning of the statute. 9 Blasphemy, he said, could be described as a "wilful and malicious attempt to lessen man's reverence for God, by denying his existence, or his attributes as an intelligent creator, governor and judge of men," and the statute prohibited the "wilful denial of God . . with an intent to impair and destroy the reverence due to him." ${ }^{10}$ Upon studying the other parts of Kneeland's publication to discern the motive and intent behind the words, so that the language would be understood as to its true meaning, it was his perception that the letter contemplated a denial of the existence of God rather than an expression of Kneeland's disbelief in the Universalists' conception of god. Therefore, it was to be "taken as proved" that the language was used with the purpose and design of denying God, and this gave sufficient grounds for conviction under the statute. 11

It was "somewhat late," suggested Shaw, to question the validity of the statute. 12 A 50-year record, and recent re-enactment after careful revision, demanded respect.

Neighbouring states had declared blasphemy to be a crime at

${ }^{8} 20$ Pickering, 211.
${ }^{10}{ }_{\text {Ibid., 213. }}$ Ib 216.
${ }^{12}$ Ibid., 218.


common law, and Kent, in People v. Ruggles ${ }^{13}$ had emphasized the inherent Christianity of the common law which, it was imputed, Kneeland had now offended. He was not protected by Article 16 of the Massachusetts Declaration of Rights. Narrowing its scope to the common law definition of a free press, Shaw construed it to mean only an absence of prior restraint, which left the individual citizen responsible for all offences committed through language, printed or oral. Any other construction, he said, would suggest a general license to pen scandal and calumny or provoke incitement, and this he deemed absurd, impractical, and inconsistent with the existence of free government.

Nor could Shaw find in Article 2, which guaranteed religious liberty, any reason for invalidating the statute, for its intent was merely to "restrain and punish acts which have a tendency to disturb the public peace," such as wilfully blaspheming the holy name of God. It did not prohibit free discussion for the "honest purpose" of discovering truth, nor even the "simple and sincere avowal of a disbelief in the existence of a supreme, intelligent being."14

In his dissent, Justice Morton, Democrat, civil

${ }^{13}$ Johnson's Reports (New York) 290 (1811). Ruggles was a "toper in New York who, being ejected from a tavern, stood in the street and shouted that Jesus Christ was a bastard and Mary a whore," which Chancellor Kent regarded as an outrage upon public decorum. Open blasphemy, he said, which reviled the religions professed by almost the whole community, was inconsistent with the peace and safety of the state: Miller, The Life of the Mind in America, 194.

${ }^{14} 20$ Pickering, 221. 
libertarian and Baptist, focused upon Kneeland's contention that the statute against blasphemy infringed upon freedom of conscience, of discussion, and of the press. Yet the power to declare a statute void, "high, delicate, if not dangerous," demanded great prudence, particularly when such statute had received frequent legislative attention. ${ }^{15}$ The history of the freedom of the press, he declared, suggested that the framers of the constitution wished to prohibit censorship only by means of previous restraints, and no immunity from liability for injuries inflicted on others was offered. From the formation of the government of Massachusetts, libels had been deemed to be crimes, and punished "by virtue of a constitutional adoption of the common law," therefore it was his intention to accept the constitutionality of the law, and await the voice of the people through the legislative channel in a definition of those who disturbed the peace with malicious falsehoods, or obscene or profane publications or exhibitions. 16

Article 2, Morton believed, secured to the individual freedom to worship God according to his conscience, provided that he did not disturb the public peace, and the right to advocate and disseminate his thoughts, if they did not wound the feelings of others. This "clearly [did] not include atheists," whose sentiments and expressions could haraly be called religion. Yet a broad view, which sanctioned the 
protection of all beliefs and disbeliefs upon the subject of religions could honour the natural transformations of faith, for which man was responsible to the Deity alone. ${ }^{17}$

These two articles, therefore, guaranteed, in his view, the right of every citizen to "form, enjoy and promulgate such opinions upon any subject as his own judgment shall dictate."18 Any law which punished a denial of God couched in language inferring a bad intent to wound feelings and corrupt principles, must be deemed constitutional. A "wilful" denial was not of itself blasphemy, for wilful meant intentional or, at worst, obstinacy, and "every person has a constitutional right to discuss the subject of God and to affirm or deny his existence." To constitute a crime, "there must be an infringement of the rights of others and a malicious purpose."19 Criminality depended upon constructive intent.

"This conviction," Morton said, "rests very heavily upon my mind." 20 clearly he feared that the court had been guilty of religious persecution. Though he believed Kneeland's public letter had been correctly interpreted as an intentional denial of God, this, he was persuaded, Kneeland had a legal right to do. Commonwealth v. Blackington (1837) concerned an attempt by the enemies of temperance reform in Massachusetts to

$$
\begin{array}{ll}
17 \text { Ibid., 233. } & { }^{18} \text { Ibid., } 236 . \\
{ }^{19} \text { Ibid., 244-5. } & 20_{\text {Ibid., }} 245 .
\end{array}
$$


break government regulation of the liquor trade. The defendant had been indicted under an 1832 statute for retailing spiritous liquors without a license. He contended in the lower court that he had been a licensed retailer in 1835 , and that the county commissioners, left to their discretion by law to license as many applicants as they believed the public good might require, had refused to grant any licenses the following year. The effect of this stand, he maintained, was to restore to every citizen of the county the right to sell, but the court instructed the jury that the commissioners' neglect did not constitute a legal defence, and the jury found against him.

The defendant's counsel, Robert Rantoul, argued that the liquor law was unconstitutional as an invasion of property rights, and as a violation both of the equal privileges clause of the Massachusetts Declaration of Rights and the act of 1837 . The Chief Justice rejected the contention that, where a power was not lawfully exercised by one qualified, it might be legally appropriated by an unqualified individual. Neither was the statute of 1832 voided by the 1837 act, which conferred upon the county commissioners the authority to refuse all licenses, even though it seemed to infer that, at the time of the offence under indictment, this power was wanting. He believed that the statute of of 1837 was "rather a declaration of what the true meaning 
of what the former act was, than an enactment introductive of a new law." 21

of greater moment was, however, the objection to the liquor license laws as contrary to the constitution of the Commonwealth. Cognizant as he was, that the judicial department was clearly vested with the power of review, it would be utilized only with "great caution and deliberation."22 For the state's constitution establishing as it did a few fundamental principles to guide each department in the fulfilment of its functions, and securing through the Declaration of Rights a social order long enjoyed under a government "nearly as free, and practically nearly as popular, as the lot of humanity would admit," had invested in the legislature the:

Full power and authority to make, ordain, and establish all manner of wholesome and reasonable orders, Iaws . . . not repugnant to the constitution . . . as they shall judge to be for the good and welfare of the Commonwealth. - . The power is the general rule, the restraint of it the specific exception. 23

In discussing, therefore, those natural rights which the defendant believed had been circumscribed, Shaw declared that laws, designed to "define, secure and give practical efficacy" to the right to acquire and possess property, which had been a subject of legislative solicitude since the first settlement of the country, imposed salutary regulations to benefit or protect commerce and trade, through
2112 Pickering, 352.
2212 Pickering, 356. 23 Ibid. , 356-7. 
which property was procured, and had never been deemed unconstitutional. All inspection and licensing laws were of this nature, made "with a view to revenue, to health, to peace and good morals"; spiritous liquors, though not necessarily immoral, tended to "immorality, or other mischief or inconvenience to the community or to individuals." 24 Neither did the licensing laws infringe the exclusive privileges clause of the Declaration of Rights, for these franchises were granted for services and duties "rendered at the times and in the manner most beneficial to the public," which meant that the security, morals and good order of the community were promoted. This "obvious purpose" rendered it free from any censure in the context of vested rights. 25

In Commonwealth v. Jailer of Alleghany County (1838), the Pennsylvania Supreme Court, interpreting the constitutional guarantee of the 14 th section of the state's Declaration of Rights, that the "privilege of the writ of habeas corpus shall not be suspended unless where in case of rebellion or invasions the public safety may require it," refused the privilege to a prisoner deemed still infectious from small pox. Stating that the purpose of the section was "to prevent wilful and oppressive delay," the court believed that it was serving the legitimate needs of society by raising an exception to the "letter of the act: "A court is not

$$
24 \text { Ibid.. } 357 . \quad 25 \text { Ibid., } 358 .
$$


bound to peril life in an attempt to perform what was not intended to be required of it." 26

In Maxon V. Annas (1845), the Chief Justice of New York's Supreme Court refused the "tranquilizing sustenance" 27 of a sunday law to a seventh Day Baptist. In the lower court, where the trial was held on a saturday, a judgment was rendered against the plaintiff for damages, and his wagon and cutter were sold. Bronson, in construing the statute of 1839, "In relation to the Seventh Day Baptists," 28 found that, though the law protected the plaintiff from any "writ, process, warrant, order, judgment, decree or other proceeding of any court," he was not sheltered from judgment that was rendered: "The rendition is a very different thing from the execution of a judgment." 29 Though, at the common law, Sunday was dies non judicus, and though a state law declared that no court could transact business on Sunday except to receive a verdict or discharge a jury, no such requirements pertained to saturday. If the process in the lower court was made returnable at a time when the defendant could not conscientiously attend to make his defence, the plaintiff deserved the "serverest censure," but the judgment could not be voided. 30

267 watts, 366 .

27 Mark De Wolfe Howe, The Garden and the Wilderness: Religions and Government in American Constitutional History (Chicago, 1965), 96.

$$
\begin{aligned}
& 28, \text { Denio, } 205 . \\
& 30, \text { Denio, } 207 .
\end{aligned}
$$


By using the principle of non-establishment in the religious guarantee clause, an assurance that liberty would not be infringed, the court could have made an effort to safeguard Maxon's spiritual commitment to his creed, but freedom of religion was not to be understood as a philosophical absolute. Even as the privilege of the writ of habeas corpus, the most basic of all protections against the authority of the state, was subject to interpretation, the courts could, in their decisions, substantially influence both the structure and atmosphere of democratic life.

Americans, Tocqueville had written, acknowledged the moral authority of the reason of the community as they acknowledge the political authority of the mass of the citizens, and "they hold that public opinion is the surest arbiter of what is lawful or forbidden, true or false." 31 Yet, the power of the majority was itself not unlimited--"above it in the political world [are] vested rights." 32 Further, the judge was "most strictly bound" to obey the constitution, which was the "origin of all authority . . the first of laws." 33 These four cases suggest, however, that Tocqueville, despite his intimate knowledge of, and insights into, the capabilities and caprices of lawyers, had misjudged the willingness of the bench, "the most powerful

$$
\begin{aligned}
& { }^{31} \text { Tocqueville, Democracy in America, I, } 393 . \\
& { }^{32} \text { Ibid., 416. }
\end{aligned}
$$


existing security against the excesses of democracy," 34 to protect minority rights against majoritarian views which the judges shared. Herein lies the proof--and the paradox--of Tocqueville's majoritarian thesis. 


\section{CHAPTER V}

\section{Conclusion}

By the middle of the nineteenth century, the doctrine of judicial review had matured; general public acquiescence therein appears to have been attained. The power equation between legislature and judiciary had been subtly reshaped. Why?

Despite its auspicious beginnings as the primary department of government in the early decades after the Revolution; despite the enlightened accomplishment of constitutions and bills of rights, and the momentum gained in this creative period, the potential of legislative promise was unfulfilled. Though there were leaders of exceptional ability, such as Calhoun and Webster, the mass of legislators justified Tocqueville's complaint that the race of American statesmen had dwindled. 1 Because the preparation of bills was delegated to legislative committees, a system, as Tocqueville had noted, which lacked method and continuity, legislation was often imperfect, and amendments and supplements created confusion and uncertainty. Special

${ }^{1}$ Tocqueville, Democracy in America, I, 200, 204: "On entering the House of Representatives at Washington, one is struck by the vulgar demeanour of the great assembly its members are almost all obscure individuals." 
legislation, which raised questions about the separation of powers, and dubious influence, gave rise to much litigation, and led to provisions in state constitutions to prohibit or limit its use. ${ }^{2}$ scepticism of legislators who, unemcumbered by scruples, embarked upon extravagant internal improvement schemes which led to the financial collapse of several states following the panic of 1837, transformed the attitudes of many regarding the proper use of public credit, and led to the drafting of new constitutions in the 1840's. Tocqueville's majority, therefore, searching for a workable solution through the medium of constitutional conventions, placed substantial limitations upon legislative discretion, and, to diffuse political authority, increased the number of elected officials, including judges, subjecting themselves, as Tocqueville would say, to the necessity of "refining [their] discretion and improving [their] choice." 3

The determinate illustration of the failure of the legislature as the crucible of the people's will lies in the collapse of the codification movement. During this, the formative era, when it was deemed necessary to give effect to the maxims of the common law which, in large part, had been incorporated in the national and state constitutions,

2Pound, The Formative Era of American Law, 53-4, 65-8.

3 Tocqueville, Democracy in America, I, 205. The indirect election of the senate appealed to him. He felt that it would avoid the risk of "perishing miserably amongst the shoals of democracy." See also Kelly and Harbison, The American Constitution, 322-3. 
codification, Roscoe Pound believed, could only be accomplished efficaciously after an era of legal maturity, "which was still well in the future." 4 Though some few codes received legislative sanction in the $1830^{\prime} \mathrm{s}$, in general they lost out to "the lawyers' desire to monopolize a profitable mystery." 5 The future lay in judicial finding rather than the legislative declaration of law in codes.

Though the Democracy had created the framework for the egalitarian revolution, and had captured the public mind, the reactionary thrust of Democratic social belief obstructed the impulse of popular rule. Pursuing the Jeffersonian myth of a simple, frugal government, the party's commitment to minimum administration hindered the regulation and supervision of the public's subsidies in

${ }^{4}$ Pound, The Formative Era of American Law, 154, 3: He dates the formative era from the establishment of the Constitution to the Civil War.

${ }^{5}$ Miller, The Life of the Mind in America, 253. Haar, in the Golden Age of American Law, 232, quotes a member of Kentucky's constitutional convention in 1849, who protested the "great expense" of codification incurred in the state of Louisiana, but this argument was probably spurious. Of more moment was the determination of the legal profession to protect its vested interest in special knowledge and procedures; the suggestion that no established legal rules could be so perfect that they could be preserved in changing social conditions, that the law was already too technical for Everyman to be his own lawyer, and that the common law was sufficiently systematized (and depoliticized) by the great commentories, which, in Pound's view, were the "stabilizing agency" of change. Pound, The Formative Era, 143. Of course, the rift between slave and free states augmented the obstacles in the way of general codification, for code provisions, once enacted, would represent absolute values, which would be held binding. To bury national peculiarities within a general formula appeared to be impossible. 
private enterprise. ${ }^{6}$ Further, determination to resist reforms from the North caused pro-slavery Democrats to check the momentum towards universal white male suffrage in the South, 7 and to organize congressional "gag" resolutions in $1836 .^{8}$ Philosophical sensitivities regarding the inherent inequality of persons not only inevitably opposed the extension of the vote to Northern blacks, but completed, in 1844, the undemocratic tendency to remove the suffrage from women. 9

Nor was the era's supposed egalitarianism reflected in the president's conception that, as the national leader, political predominance belonged to him. The bank veto provides a crucial example. Though he correctly perceived

6 Wallace D. Farnham, "the Weakened Spring of Government," American Historical Review, 68 (1963), 662-80, where he discussed the lack of a defined policy towards emerging issues. However, the people's representatives were no less eager, on occasion, to still the popular voice, for, seeking to stimulate economic development in five states in 1830-5, they suppressed the popular role in the assessment of damages arising out of public works by eliminating the jury: Horwitz, The Transformation of American Law, 143.

${ }^{7}$ Schwartz, The Law in America, 45: For instance, giving to the conservatives, led by the aged John Marshall, a victory in the Virginia Convention of 1839-40.

${ }^{8}$ Hyman and Wiecek, Equal Justice under the Law, 9, to muzzle abolitionists.

${ }^{9}$ Edward Pessen, Jacksonian America, Society, Personality and Politics (Chicago, 1969), 87: Women possessed the vote in the first years of the Revolution in several states. The Jacksonian era witnessed the deprivation of this right in state after state, ending with New York in 1844. Ibid., 322: The Van Burenites in New York "took the lead in modifying the state constitution to make it close to impossible that any citizen of color would vote." Ninetythree percent of Northern blacks lived in states which deprived them of the suffrage. 
Jackson to be both the master and servant of the Democratic party, Tocqueville believed that he would not forfeit his political position by imprudently elevating the executive role. 10 In this he was wrong. Realizing the potential latent in the executive office, Jackson evolved a new conception of presidential authority and new instruments of power over the people by his use of the veto, by his position as party leader, and by his control of appointments and removals. Similarly, popular influence in the major parties was "more nominal than real"; state political machines were essentially impervious to the people's control. ${ }^{11}$

The traditionalism of the political establishment in Washington, and its espousing of the ideology of laissez faire and rugged individualism, determined the fundamental failure of the Democracy to shape the course of economic development during crucial transition years. This individualist, activist bias of Jacksonianism, with its stress on the free, responsible will of the individual in a challenging social and physical environment, limited the authority of government to interfere with the autonomy of private decision makers. Indeed, preference for the delegation of power over the general public appeared "natural to the times."12 Great distances and federalism, scarce cash and problems

10 Tocqueville, Democracy in America, I, 413-4.
11 Pessen, Jacksonian America, 340.
12 Hurst, Law and the Conditions of Freedom in Nineteenth Century United States, 65. 
over a tax base, and the Democracy's failure to fashion an efficient bureacracy because of the Spoils System (itself hardly democratic), invited the development of a variety of unofficial practical solutions, and the commission of authority to private groups to provide for community needs. ${ }^{13}$

At a time when men turned their prime energies away from public policy to private affairs; at a time of high social mobility, when there were few depressed groups without any prospect of bettering their condition, ${ }^{14}$ the courts were available to provide legal tools and procedures to enforce valid agreements. More continuously in session than the legislatures, and with better trained and disciplined personnel, insulated from special interest pressures by tenure, (still the norm in some states, though waning), they created the framework for coherent economic planning, a role justified while private interest fulfilled essential public needs.

A range of procedural changes affecting the functioning of the courts had swept away dead forms, facilitating practice, though some, as the changing role of the jury demonstrates, decreased the participation of the people in

13 After the Whiskey Rebellion and the house tax riots in Pennsylvania, the government was cautious about employing its fiscal power. See Tocqueville, Democracy in America, II, 109-110, where he discussed the formation of associations to serve societal needs.

${ }^{14}$ Ibid., II, 136-8, 141, 156-7, 243-5. 
the judicial process. 15 Legal education, with its proliferation of schools, court records and periodicals enabled the bench to achieve high standards of intellectual eminence, and to secure a favourable public image. Commentaries and doctrinal writings by teachers such as Kent and story gave to the courts, at a critical period, authoritative statements on the common law, and provided the basis of a taught tradition, fixing the reception of the common law for all jurisdictions, except one. 16 Judicial development of the common law as based on the natural law concept of a universal ideal form of law, permitted the courts to present the Constitution as a model political text; judicial deference to the common law doctrine of supremacy of the law, and to the Constitution as the creation of the genius of the American people, enhanced its disciplinary power. ${ }^{17}$ By means of judicial empiricism, judges gave content to abstract constitutional precepts, and procedural forms, and judged legislative activities thereby.

In using law to regulate behavior and shape the environment during a period of transition from pioneer, agricultural to urban, industrialized America, the courts applied an individualist ideal of society, favourable to private individual and group liberty, with rare exceptions. This,

15 Haar, The Golden Age of American Law, 200.

16 Pound, The Formative Era of American Law, 144, 151. That one was Louisiana.

${ }^{17}$ Ibid., 105, 108. 
coinciding with the strain of Jacksonian idealism which had emphasized the social desirability of free individual decision and self-assertion, gave vitality to the use of law to promote private entrepreneurial activities. After the Civil War a major shift in economic and political power at the expense of the farmer, the worker and the consumer would make a mockery of democratic authority and aspirations. The work ethic, upon which the nation had been reared, which sanctified individual economic achievement, would be prostituted by those who were able to exploit the avenues of wealth afforded by this fluid, competitive society.

It is in the formative era, as these cases demonstrate, that judges, perceiving themselves to be the ideological heirs of the founding fathers, "imposed their own views of proper economic and social policy upon the nation."18 in the process, though they provided the mechanism whereby minorities might overturn the political judgments of the majority, as Tocqueville's majoritarian theory had suggested, they failed to protect manifestations of individualism dissociated from traditional beliefs about correct conduct, no matter that these were sheltered by the Bills of Rights. Behavior deemed reprehensible, deviant or blasphemous received no legal sanction from conservative courts committed to social order, but not to civil liberties. This, Tocqueville had not foreseen. 
The Frenchman's distinctive contribution to the philosophy of democracy, it must be remembered, was intended for a European audience. If his majoritarian thesis, with its dark forebodings that challenged the workability of the elective principle, appears to be a simplistic formula, which did not adequately explain the contradictory pressures that operated in American society at any given moment, its conclusions addressed the profound issues which deeply troubled his countrymen as they weighed the prospects of further revolutionary changes.

Neither his emphasis on the power of the majority, nor the indispensability of judicial authority as a neutralizing agent, were sustained by another nineteenth century political analyst. The Jacksonian, Frederick Grimke, writing in the mid-1840's, stressed that public opinion, broadly based, offered a guarantee of stability through the balance of competing forces in government and society, especially political parties; ${ }^{19}$ universal manhood suffrage diffused political authority. He believed that the judicial department had a "disproportionate share of importance," 20 and, his years on the Ohio supreme Court having convinced him of the fallibility of the judicial character, he feared the elevation of judges above community surveillance, with the consequent encouragement of a dangerous gap between judicial doctrines

${ }^{19}$ Frederick Grimke, The Nature and Tendency of Free Institutions, ed. John w. Ward (Cambridge, 1958). ${ }^{20}$ Ibid., p. 438 . 
and evolving social needs. If they were to be accountable to the public, judges should be elected to office for only such a sufficient number of years that they might demonstrate their competence without losing their dependence upon the community. 21 He saw the institution of the jury as a "wide and salutary influence upon the administration of justice," a competent and equitable arm of law proceedings. 22

The return to Tocqueville's hypotheses, however, by an ultra-conservative political scientist, occurred with the publication of Francis Lieber's On Civil Liberty and SelfGovernment. Though he placed far greater emphasis on the protection of civil rights, he denounced universal manhood suffrage as leading to "serious misrule," 23 because the voting privilege was not granted upon the basis of property: "We seek for a criterion which will enable us to distinguish those who have a fair stake in the welfare of the state from those who have not." 24 He believed that the judicial power ought to be independent, and conservative, for judges were "the brakes which prevent the vehicle from descending too fast on an inclined plane."25 In 1859, the elected judiciary was, in his opinion, "universally and unqualifiedly a serious failure"; 26 the confidence of the people in the

$$
21 \text { Ibid. 449-62. } 22 \text { Ibid. 463-4. }
$$

${ }^{23}$ Francis Lieber, On Civil Liberty and Self-Government, ed. Theodore D. Woolsey (New York, 1972), 262.

$$
2{ }^{24} \text { Ibid., 173. } 25 \text { Ibid., } 226 .
$$


judicial system had decreased, with a consequent decline in esteem for the jury system. Yet the institution had its positive aspects, for it "enables plain, common and practical sense properly to administer itself with keen professional and scientific distinction," providing a school of free citizenship. 27

The principle that political power should be exercised subject to fundamental limitations embodied in a written constitution is an American tradition which reaches as far back as the Mayflower Compact. Constitutional guarantees give notice that ideals of justice and liberty lie within a protective shelter. Nevertheless, as has been demonstrated, the courts could deliberately dispossess perceived aberrant individuals of civil liberties deemed cumbrous and untimely. All of these cases throw into bold relief the magnitude of the judicial policy-making power, a perplexing question which speaks to the legitimacy of judicial review. Though, by tacit consent of the people, this power is accepted, it ought always to be remembered that Bills of Rights, albeit self-imposed, are not self-enforcing. "The true friends of the liberty and the greatness of man," wrote Tocqueville, "ought constantly to be on the alert to prevent the power of government from lightly sacrificing the private rights of individuals to the general execution of its designs." 28

$$
\begin{aligned}
& 27 \text { Lieber, On Civil Liberty and Self-Government, } 233-4 \text {. } \\
& { }^{28} \text { Tocqueville, Democracy in America, II, } 327 .
\end{aligned}
$$




\section{TABLE OF CASES}

PAGE

Brown v. Brown, 6 Watts, 54 (1837) . . . . . . . . . . 20 Budd v. State, 3 Humphreys, 428 (1842) . . . . . • . . 50 City of Boston v. Shaw, 1 Metcalf, 130 (1840) . . . . . 38 Clippinger v. Hepbaugh, 5 Watts and Sergeant, $315(1843)$

Commonwealth v. Abbott, 13 Metcalf, 120 (1847) . . . . . 29 Commonwealth v. Anthes, 5 Gray, 185 (1855) - • • . 28, 29 Commonwealth v. Blackington, 12 Pickering,

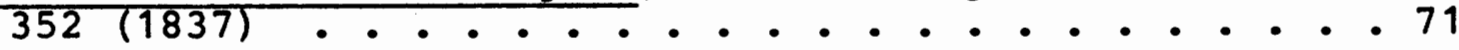
Commonwealth v. Collins, 8 Watts, 331 (1839) • . . . . . 42 Commonwealth v. Jailer of Alleghany Co.' 7 Watts, $366(1838)$. . . . . . . . . . . . . . 74

Commonwealth v. Kneeland, 20 Pickering, 206

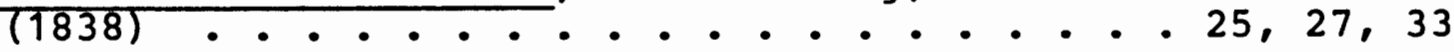

Commonwealth v. Mann, 5 Watts and Sergeant, $403(1843)$. . . . . . . . . . . . . . . . . . 45 Commonwealth v. Porter, 10 Metcalf, $263(1845)$. $26,32,33$ Commonwealth v. White, 10 Metcalf, 14 (1845) . • . . . 26 Dale v. State, 10 Yerger, 554 (1837) . . . . . . . . . 24 DeBow v. People, 1 Denio, 10 (1845) . . . . . . . . . . . 61 Green v. Allen, 5 Humphreys, 170 (1844) • • • • • • • • 52 Governor v. Porter, 5 Humphreys, 165 (1844) • • • • • . 51 In the Matter of John and Cherry streets, 19 Wendell, $659(1839)$. . . . . . . . . . . . . . 55 Jones' Heirs v. Perry, 10 Yerger, 59 (1836) • . . . 48, 50 
Kolb's Case, 4 Watts, 154 (1835) . . . . . . . . . 19

Leib v. Commonwealth, 9 Watts, 200 (1839) . . . . . 40 Maxson V. Annas, 1 Denio, 204 (1845) . . . . . . . 75 McCorry v. King's Heirs, 3 Humphreys, 277 (1842) . •. . 24 McGowan V. State, 9 Yerger, 185 (1836) . . . . . 22, 24 Norman v. Heist, 5 Watts and Sergeant, 171 (1843) . • 43 People v. Canal Appraisers, 13 Wendell, 355

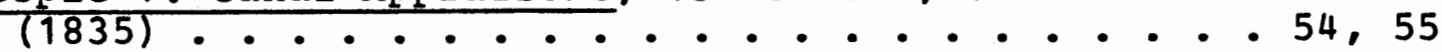
People v. Kane, 23 Wendell, 414 (1840) . . . . . . 59 People v. Rathbun, 21 Wendell, 509 (1839) . . . . . 17 People v. Warner, 7 Hill, 81 (1845) . . . . . . . . 62 Purdy v. People, 4 Hill, 384 (1842) . . . . . . 60,62 Quakenbush v. Danks, 1 Denio, 128 (1845) . . . . . . 62 Richardson v. Wilson, 8 Yerger, 79 (1835) . . . . . 47 Stone v. Crocker, 24 Pickering, 11 (1839) . . . . . . 25 Sypher v. Long, 4 Watts, 253 (1835) . . . . . . . 20 Taylor v. Porter and Ford, 4 Hill, 140 (1843) . . . . 57 VanHook v. Whitlock, 26 Wendell, 43 (1841) ...... 60 $\frac{\text { Worcester } v \text {. Western Railroad Corporation, }}{4 \text { Metcalf, } 564(1842) \cdot \text {. . . . . . . 39 }}$ Yoter v. Sanno, 6 Watts, 164 (1837) . . . . . . . . 21 


\section{A SELECTED BIBLIOGRAPHY}

\section{BOOKS}

Arieli, Yehoshua. Individualism and Nationalism in American Ideology. Cambridge: Harvard University Press, 1964.

Bailey, Thomas A. A Diplomatic History of the American People. Princeton: Princeton University Press, 1970.

Benson, Lee. The Concept of Jacksonian Democracy: New York as a Test Case. Princeton: Princeton University Press, 1961.

Boudin, Louis B. Government by Judiciary. New York: Russell Press, 1932 .

Folmsbee, Stanley F., et al. Tennessee, a Short History. Knoxville: University of Tennessee Press, 1969.

Friedman, Lawrence M. A History of American Law. New York: Simon and Schuster, 1973.

Gabriel, Ralph H. The Course of American Democrat Thought: An Intellectual History since 1815. New York: The Ronald Press, 1940.

Grimke, Frederick. The Nature and Tendency of Free Institutions. Ed. John W. Ward. Cambridge, Harvard University Press, 1968.

Haar, Charles. The Golden Age of American Law. New York: Braziller, George, Inc., 1965.

Hartz, Louis. The Liberal Tradition in America: an Interpretation of American Political Thought Since the Revolution. New York: Harcourt, Brace, Inc., 1955.

Howe, Mark DeWolfe. The Garden and the Wilderness: Religion and Government in American Constitutional History. Chicago: University of Chicago Press, 1965.

-- Readings in American Legal History. Cambridge: Harvard University Press, 1949. 
Horwitz, Morton J. The Transformation of American Law.

Cambridge, Harvard University Press, 1977.

Hurst, James Willard. Law and the conditions of Freedom in Nineteenth-Century United States. Madison: University of Wisconsin Press, 1956.

Hyman, Harold M. and Wiecek, William M. Equal Justice Under

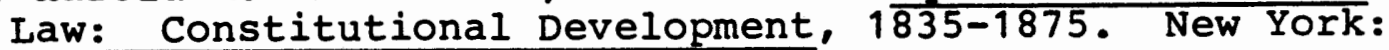
Harper and Row, 1982 .

Kelley, Alfred H. and Harbison, Winfred A. The American Constitution, its Origins and Development. New York: W. W. Norton and Co.. 1970 .

Levy, Leonard $w$. The Law of the Commonwealth and Chief Justice Shaw: The Evolution of American Law, 18301860. New York: Harper and Row, 1957.

Lieber, Francis. On Civil Liberty and Self-Government. Philadelphia: Iippincott, 1877.

Lively, Jack. The Social and Political Thought of Alexis de Tocqueville. Oxford: Oxford University Press, 1962 .

Meyers, Marvin. The Jacksonian Persuasion. Stanford: stanford University Press, 1957.

Miller, Perry. The Life of the Mind in America: From the Revolution to the Civil War. New York: Harcourt, Brace, 1965.

Pessen, Edward. Jacksonian America: Society, Personality and Politics. Chicago: Dorsey Press, 1969.

- New Perspectives on Jacksonian Parties and Politics. Boston: Allyn and Bacon, Inc., 1969.

Pound, Roscoe. The Formative Era of American Law. Boston: Little, Brown and Co., 1936.

Richardson, James D. A Compilation of Messages and Papers of the Presidents, 1789-1897. Washington: Government Printing Office, 1896.

Rossiter, Clinton, ed. The Federalist Papers. New York: The New American Library, 1961.

Schleifer, James T. The Making of Tocqueville's Democracy in America. Chapel Hill: University of North Carolina Press, 1980.

Schlesinger, Arthur M. Jr. The Age of Jackson. Boston: Little, Brown and Co., 1945. 
Schwartz, Bernard. The Law in America: A History. New York: McGraw Hill, 1974 .

Shaw, Livermore, Jr. The Twilight of Federalism: the Disintegration of the Federal Party. New York: Gordian Press, 1972.

Thorpe, F. N., ed. The Federal and State Constitutions: Colonial Charters and other Organic Laws in the States, Territories, and Colonies Now and Heretofore Forming in the United States of America. Washington: Government Printing office, 1909.

Tocqueville, Alexis de. Democracy in America. 2 vols. Ed. Phillips Bradley. New York: Alfred A. Knopf, 1966.

Van Deusen, Glyndon G. The Jacksonian Era, 1828-1848. New York: Harper and Row, 1959.

Warren, Charles. A History of the American Bar. New York: Longwood Press, 1939.

Welter, Rush. The Mind of America, 1820-1860. New York: Columbia University Press, 1965.

zetterbaum, Marvin. Tocqueville and the Problem of Democracy. Stanford: Stanford University Press, 1966.

\section{ARTICLES}

Farnham, wallace D. "The Weakened Spring of Government." American Historical Review, 68 (1963), 662.

Howe, Mark De Wolfe. "Juries as Judges of Criminal Law." Harvard Law Review, 52 (1939), 582.

McCormick, Richard P. "New Perspectives in Jacksonian Politics." American Historical Review, 65 (1960), 300.

Nelson, William E. "Changing Conceptions of Judicial Review." University of Pennsylvania Law Review, 120 $(1972), 1166$.

"The Changing Role of the Jury in the Nineteenth Century." Yale Law Journal, 74 (1964), 170. 